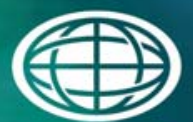

Savannah River

National Laboratory ${ }^{m}$

OPERATED BY SAVANNAH RIVER NUCLEAR SOLUTIONS

\title{
Measurement of Offgas Species from Thermal Decomposition of Simulated DWPF Melter Feed
}

J. W. Amoroso

J. R. Zamecnik

September 2014

SRNL-STI-2014-00286, Revision 0 


\section{DISCLAIMER}

This work was prepared under an agreement with and funded by the U.S. Government. Neither the U.S. Government or its employees, nor any of its contractors, subcontractors or their employees, makes any express or implied:

1. warranty or assumes any legal liability for the accuracy, completeness, or for the use or results of such use of any information, product, or process disclosed; or

2. representation that such use or results of such use would not infringe privately owned rights; or

3. endorsement or recommendation of any specifically identified commercial product, process, or service.

Any views and opinions of authors expressed in this work do not necessarily state or reflect those of the United States Government, or its contractors, or subcontractors.

\section{Printed in the United States of America}

Prepared for U.S. Department of Energy 
Keywords: Offgas, redox, glycolic, nitric, formic, DWPF, antifoam, flowsheet

Retention: Permanent

\section{Measurement of Offgas Species from Thermal Decomposition of Simulated DWPF Melter Feed}

J. W. Amoroso

J. R. Zamecnik

September 2014

Prepared for the U.S. Department of Energy under contract number DE-AC09-08SR22470.

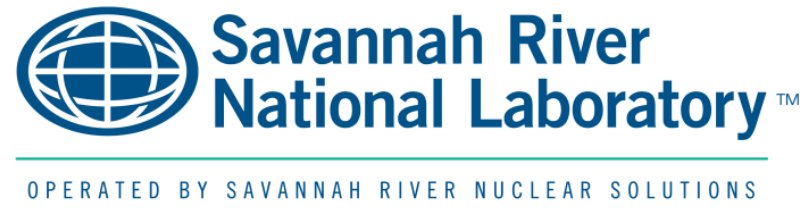




\section{REVIEWS AND APPROVALS}

\section{AUTHORS:}

J.W. Amoroso, Process Technology Programs

Date

J.R. Zamecnik, Process Technology Programs

Date

TECHNICAL REVIEW:

D. P. Lambert, Process Technology Programs, Reviewed per E7 2.60

Date

APPROVAL:

D.H. McGuire, Manager

Date

Process Technology Programs

S.L. Marra, Manager

Date

Environmental \& Chemical Process Technology Research Programs

E.J. Freed, Manager

Date

DWPF and Saltstone Engineering 


\section{PREFACE}

This report documents the findings related to the Technical Task Request (TTR) HLW-DWPF-TTR2013-0025 ("Measurement of Antifoam Degradation Products for Melter Offgas Flammability") and the associated Task Technical Quality Assurance Plan (TTQAP) SRNL-RP-2013-00093 ("Task Technical and Quality Assurance Plan for Measurement of Offgas Species from Thermal Decomposition of Antifoam 747 and DWPF Melter Feed”). 


\section{EXECUTIVE SUMMARY}

A better understanding of the decomposition process in the DWPF melter is desired to improve the melter offgas flammability model. Antifoam in DWPF is of interest because its presence contributes to the flammability of the melter offgas via formation of flammable gas species. Simulant formic/nitric and glycolic/nitric flowsheet SRAT/SME (melter feed) products were studied at several antifoam concentrations. In addition, redox measurements were compared to the offgas generation data to aid in the overall understanding of the feed decomposition process in the DWPF.

A new method for quantitatively measuring the offgas species from simulated DWPF melter feed during heating was used to measure the offgas as a function of temperature. Results indicated that the form of the antifoam (degraded, pristine, or a surrogate) had a negligible effect on the offgas composition (including $\mathrm{H}_{2}$ generation) or glass redox for the SB8 formic/nitric flowsheet. Antifoam concentration in the glycolic/nitric flowsheet feed had a negligible effect on the offgas composition (including $\mathrm{H}_{2}$ generation) and glass redox. The glycolic/nitric flowsheet feed had significantly less $(\sim 1 / 4)$ total $\mathrm{H}_{2}$ generation in the offgas during melting compared to the formic/nitric flowsheet and is thought to be related to different reaction paths among the flowsheets

The overall composition of the offgas was composed primarily of $\mathrm{CO}_{2}, \mathrm{NO}, \mathrm{H}_{2}, \mathrm{CO}, \mathrm{N}_{2} \mathrm{O}, \mathrm{N}_{2}, \mathrm{NO}_{2}$, and $\mathrm{CH}_{4} . \mathrm{CO}_{2}$ and $\mathrm{NO}$ comprised $\sim 80 \%$ of the total emitted offgas from the formic/nitric flowsheet feeds and $\sim 90 \%$ of the total emitted offgas from the glycolic/nitric flowsheet feed. The SB8 formic/nitric flowsheet feed exhibited approximately equal concentrations of $\mathrm{NO}, \mathrm{N}_{2} \mathrm{O}$, and $\mathrm{N}_{2}$. In contrast, the glycolic/nitric flowsheet feed exhibited approximately $80 \% \mathrm{NO}$, and approximately $10 \% \mathrm{~N}_{2} \mathrm{O}$ and $\mathrm{N}_{2}$. Similarly, the SB6 formic/nitric flowsheet feed exhibited approximately $70 \% \mathrm{NO}$, and approximately $15 \% \mathrm{~N}_{2} \mathrm{O}$ and $\mathrm{N}_{2}$ with the exception that for the SB6 formic/nitric flowsheet feed processed in $1 \% \mathrm{O}_{2}$ no $\mathrm{N}_{2}$ was measured but, approximately $10 \% \mathrm{NO}_{2}$ was measured. In all other feeds, $1-3 \% \mathrm{NO}_{2}$ was measured. The overall feed composition appeared to have a significant effect on the offgas composition and resulting glass redox.

The majority of nitrogen species (and most other gaseous species) were emitted over a relatively narrow temperature range from $200-400{ }^{\circ} \mathrm{C}$. A portion of the total $\mathrm{CO}_{2}$ was emitted simultaneously with the other gaseous species but, the majority was emitted more slowly until approximately $800^{\circ} \mathrm{C}$ at which point all significant offgas generation ceased. The data show that the $\mathrm{N}$-containing reactants were consumed well before the completion of $\mathrm{CO}_{2}$ evolution. The available $\mathrm{N}$ did not react to produce only $\mathrm{N}_{2}$ (and $\mathrm{CO}_{2}$ ) but rather a significant amount of intermediate products $\mathrm{NO}, \mathrm{NO}_{2}$, and $\mathrm{N}_{2} \mathrm{O}$ were measured in addition to $\mathrm{N}_{2}$. The $\mathrm{CO}_{2}$ evolution was consistent with metal carbonate decomposition further supporting the formation of intermediate $\mathrm{N}$ species during reaction.

Glass redox measurements from this study were consistent with predictions based on the measured offgas products (i.e. not all $\mathrm{N}$ reacting to form $\mathrm{N}_{2}$ ). The results from this study support the hypothesis that the chemical reaction path in the feed significantly affects the glass redox. It is believed that the feed chemistry controls the offgas composition that in turn controls the glass redox. However, it is hypothesized that the feed chemistry or the experimental setup can de-couple that relationship. 


\section{TABLE OF CONTENTS}

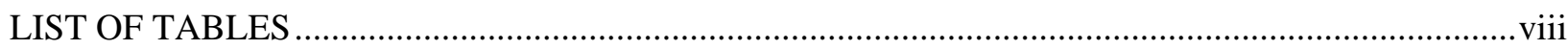

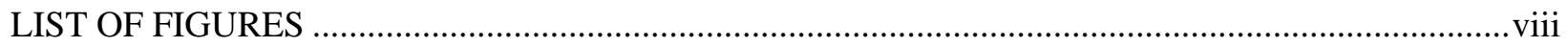

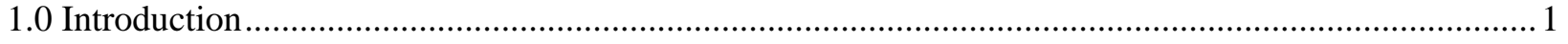

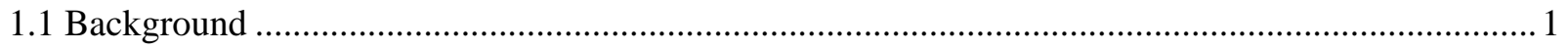

2.0 Experimental Procedure............................................................................................................... 2

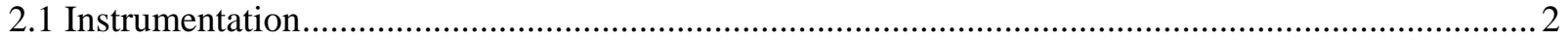

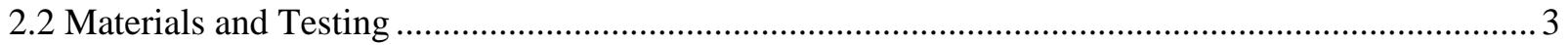

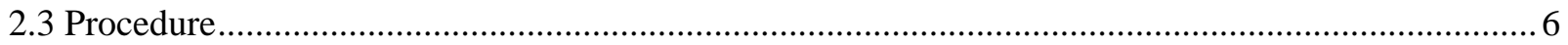

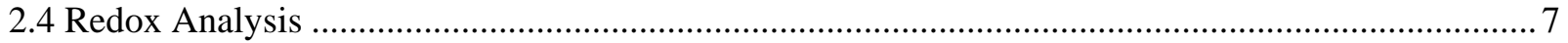

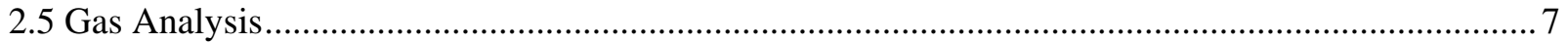

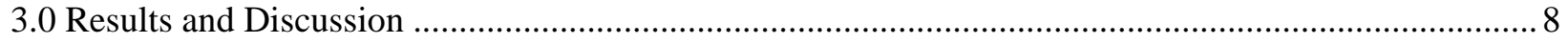

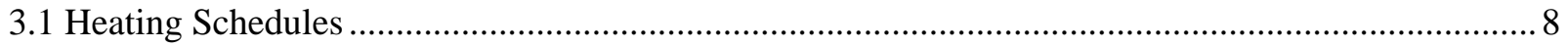

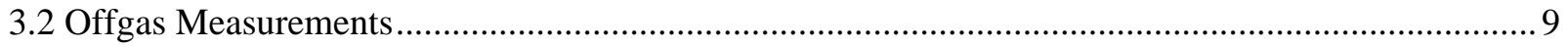

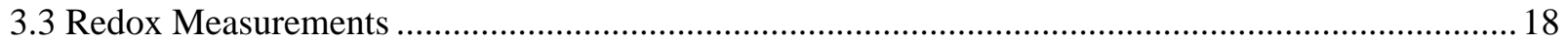

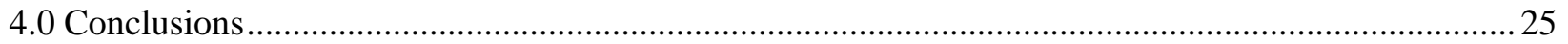

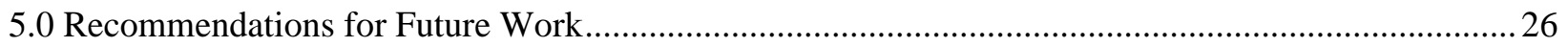

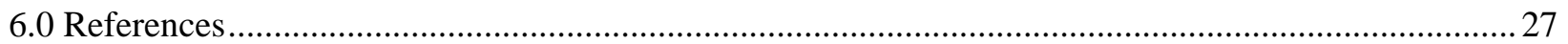




\section{LIST OF TABLES}

Table 1. Experimental sample matrix for testing........................................................................ 4

Table 2. Anion and antifoam concentrations in the testing feeds. ..................................................... 5

Table 3. Analyzers and Corrections Used for Each Species ........................................................... 8

Table 4. Redox analysis results from resulting glass products..................................................... 19

Table 5. Calculated formate [F], glycolate [G], and nitrate [N] coefficients based on single

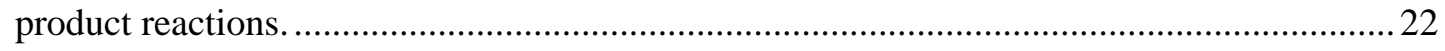

Table 6. Calculated nitrate coefficients [N] based on offgas measurements. .................................... 22

Table 7. Measured and predicted redox values using the measured offgas results from this study..... 24

\section{LIST OF FIGURES}

Figure 1. Hypothesized Antifoam Decomposition Reaction in the SRAT........................................... 2

Figure 2. Schematic drawing of quartz crucible used for testing. .................................................... 2

Figure 3. Image of quartz vessel with gas port tubing installed. (Liquid has been added to crucible to aid visualization.) Inset: Image of thermocouple and gas port tube fittings. ........ 2

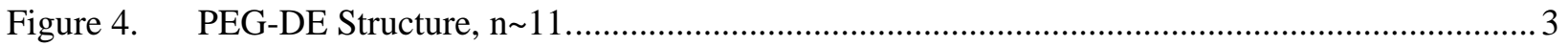

Figure 5. Calculated total molar concentration of $\mathrm{C}, \mathrm{N}$, and $\mathrm{H}$ and molar ratios of N/C and N/H

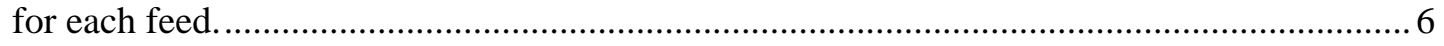

Figure 6. Thermocouple data demonstrating heating rate for each sample......................................... 9

Figure 7. Total $\mathrm{CO}_{2}$ and NO offgas generation measured with FTIR and MS for each sample. (Lines are provided to aid the eye, they do not indicate trends among samples)....................10

Figure 8. Total $\mathrm{H}_{2}, \mathrm{CO}, \mathrm{NO}_{2}, \mathrm{~N}_{2} \mathrm{O}, \mathrm{N}_{2}, \mathrm{CH}_{4}$, and $\mathrm{C}_{2} \mathrm{H}_{4}$ offgas generation for each sample.................11

Figure 9. Total calculated and total measured (evolved) moles of H, N, C, and O in each feed...........12

Figure 10. Differences (\%) between calculated and measured moles of $\mathrm{H}, \mathrm{O}, \mathrm{N}$, and $\mathrm{C}$ for each

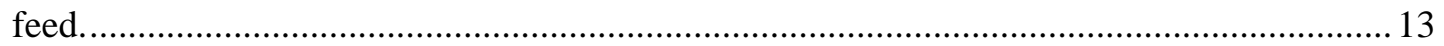

Figure 11. Cumulative $\mathrm{H}_{2}$ generation as a function of temperature from each sample. (Note temperature data above $\sim 850^{\circ} \mathrm{C}$ is not plotted for the CEF1-Baseline sample due to a thermocouple malfunctioned during that run (Refer to Section 3.1).

Figure 12. Cumulative NO generation as a function of temperature from each sample. (Note temperature data above $\sim 850^{\circ} \mathrm{C}$ is not plotted for the CEF1-Baseline sample due to a thermocouple malfunctioned during that run (Refer to Section 3.1). 
Figure 13. Cumulative $\mathrm{CO}_{2}$ generation as a function of temperature from each sample. (Note discontinuity and temperature data above $\sim 850^{\circ} \mathrm{C}$ is not plotted for the CEF1-Baseline sample due to a thermocouple malfunctioned during that run (Refer to Section 3.1)............ 16

Figure 14. Cumulative $\mathrm{CO}$ generation as a function of temperature from each sample. (Note discontinuity and temperature data above $\sim 850^{\circ} \mathrm{C}$ is not plotted for the CEF1-Baseline sample due to a thermocouple malfunctioned during that run (Refer to Section 3.1)......

Figure 15. Measured vs. predicted $\mathrm{Fe}^{2+} / \mathrm{Fe}$ Total for formic/nitric flowsheet feed samples. ................. 23

Figure 16. Measured vs. predicted $\mathrm{Fe}^{2+} / \mathrm{Fe}$ Total for glycolic/nitric flowsheet feed samples. ................ 24 


\section{LIST OF ABBREVIATIONS}

$\begin{array}{ll}\text { C } & \text { carbon } \\ \text { CEF } & \text { cold cap evaluation furnace } \\ \text { g } & \text { gram(s) } \\ \text { DWPF } & \text { Defense Waste Processing Facility } \\ \text { FTIR } & \text { Fourier transform infrared } \\ \text { HMDSO } & \text { hexamethyldisiloxane } \\ \text { kg } & \text { kilogram(s) } \\ \text { mg } & \text { milligram(s) } \\ \text { PEG } & \text { poly(ethylene) glycol } \\ \text { PEG-DE } & \text { PEG dimethyl ester } \\ \text { PVV } & \text { process vessel vent } \\ \text { SB } & \text { sludge batch } \\ \text { SME } & \text { slurry mix evaporator } \\ \text { SRAT } & \text { sludge receipt adjustment tank } \\ \text { SRNL } & \text { Savannah River National Laboratory } \\ \text { TMS } & \text { trimethylsilanol } \\ \text { TOC } & \text { total organic carbon }\end{array}$




\subsection{Introduction}

Antifoam is added to sludge during the Defense Waste Processing Facility (DWPF) pretreatment processes to prevent foaming and material carryover into the Process Vessel Vent (PVV) system prior to being fed to the melter. The antifoam (Antifoam 747) and its decomposition products remain in the melter feed and contribute to melter offgas flammability. A calculation based on theoretical assumptions about the reaction species in the melter and melter experimental data are used to control, or mitigate, the flammable species in the offgas during processing. The current understanding of the behavior of antifoam in the DWPF is that it partially decomposes in the Sludge Receipt and Adjustment Tank (SRAT) and Slurry Mix Evaporator (SME), releasing part of the antifoam molecule into the CPC PVV while the remaining decomposition products from the original antifoam molecule are fed to the melter. The amount of intact antifoam remaining in the melter feed is not clearly known.

The melter is fed to maintain a cold cap (a buildup of un-melted feed material) on the surface of the melt pool. The reactions that occur in the cold cap as a result of the atmosphere, feed composition, antifoam and antifoam decomposition products are the basis for the flammability calculation. The calculation assumes the antifoam molecule does not undergo structural changes during CPC processing, that the antifoam breaks down completely in the melter due to a thermo-oxidative decomposition that produces $\mathrm{SiO}_{2}, \mathrm{H}_{2}, \mathrm{CO}$, and $\mathrm{CH}_{4}$ products. Because antifoam decomposition is dependent on pretreatment processing time and sludge composition, experimental confirmation of the decomposition products and their effect on flammable gas generation could lead to an improvement in the flammability model. Therefore, the Savannah River National Laboratory (SRNL) developed an experimental method to qualitatively measure the thermal degradation products from simulated DWPF melter feeds.

A series of crucible-scale tests were performed to mimic the melting process in the DWPF cold cap using small quantities $(\sim 10 \mathrm{~g})$ of simulated melter feed. The tests were designed to provide data to better understand the reactions in the DWPF melter, particularly related to the antifoam decomposition products in the cold cap that contribute to the overall flammable gas generation in the melter vapor space.

The test conditions in these small-scale tests were designed for more precise offgas measurements and material balances compared to larger scale tests which require greater materials and time expenditures such as the Cold Cap Evaluation Furnace (CEF), a pilot scale offgas testing furnace. Samples of two feeds used during CEF demonstrations were evaluated as part of these small-scale crucible tests for comparison purposes.

\subsection{Background}

Antifoam is known to partially decompose in the pretreatment processes prior to being fed to the melter. The amount of decomposition depends on factors such as sludge composition, $\mathrm{pH}$, and pretreatment time in the SRAT or SME. Slurry being fed to the DWPF melter will contain a range of pristine and decomposed antifoam species depending in large part on how long the sludge is boiled after the antifoam addition.

The idealized antifoam structure is shown in Figure 1. It is believed that trimethylsiloxy (TMS) groups are initially cleaved from the antifoam molecule during SRAT and SME processing.[1] This hypothesis is supported by Fourier Transform Infrared (FTIR) spectroscopy which has detected hexamethyldisiloxane (HMDSO) (two TMS groups bound together) in the SRAT offgas. Total organic carbon (TOC) measurements of the sludge, which could help quantify and confirm this mechanism, are insufficiently accurate to quantify the loss of the TMS groups. Nevertheless, decomposition in the SRAT is shown to yield HMDSO and poly(ethylene) glycol (PEG) chains in some form.[1] 


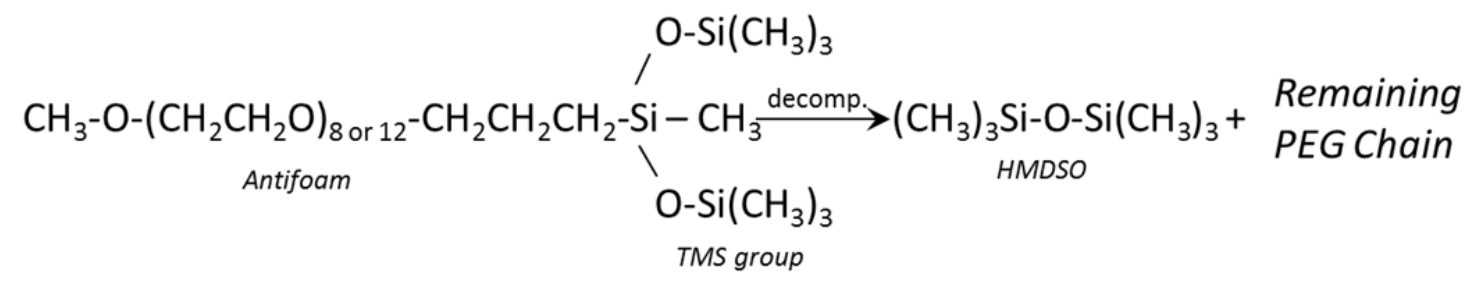

Figure 1. Hypothesized Antifoam Decomposition Reaction in the SRAT.

\subsection{Experimental Procedure}

\subsection{Instrumentation}

The experimental setup consisted of a quartz vessel containing the sample in a standard temperatureprogrammable furnace. The quartz vessel, with one outlet port and one inlet port, was designed and fabricated at SRNL for use during the experiments. The vessel was designed for one-time use and was fabricated with a conical bottom to consolidate the small quantity of feed to facilitate subsequent redox measurements of the product. The outlet port was designed to accommodate a thermocouple that was inserted directly into the melting feed. The quartz material has an advantage of being transparent so the reaction could be monitored visually. A schematic drawing of the quartz vessel is shown in Figure 2 and a digital image of an actual vessel is shown in Figure 3.

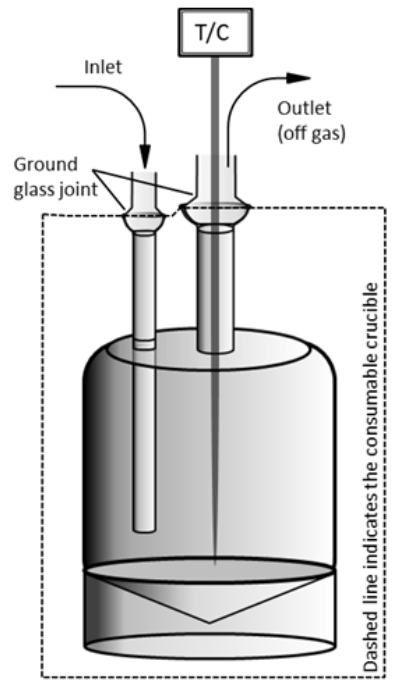

Figure 2. Schematic drawing of quartz crucible used for testing.

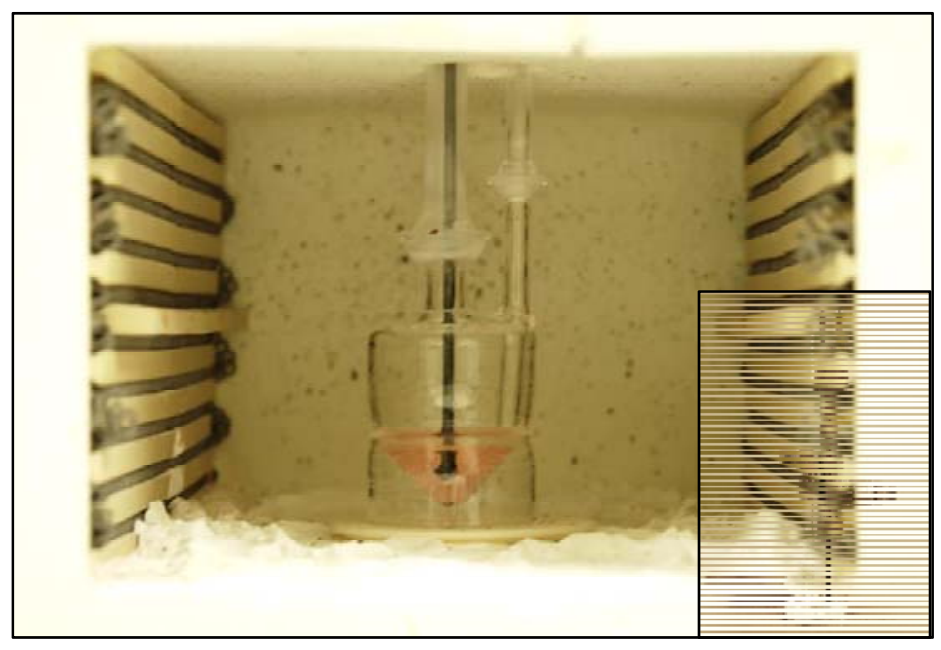

Figure 3. Image of quartz vessel with gas port tubing installed. (Liquid has been added to crucible to aid visualization.) Inset: Image of thermocouple and gas port tube fittings.

The quartz vessel was designed to seal (with ball and socket fittings) so that the atmosphere above the melting feed could be controlled throughout the duration of the experiment. The quartz vessel was purged with a known flow rate of gas to act as a carrier for the offgas species so that quantitative measurements of the gases generated could be performed. Argon was used as the primary purge gas because an inert system is believed to approximate the conditions in the reaction zones of the cold cap in the DWPF melter, which influence the model predictions.[2] An Ar/air purge was also used in one test to simulate air infiltration into the cold cap. 


\subsection{Materials and Testing}

This study intended to compare offgas reactions from melting DWPF simulant sludge processed using formic/nitric and glycolic/nitric flowsheets containing various amounts of decomposed and pristine antifoam. As part of this study, a surrogate for decomposed antifoam was studied as a possible method for removing uncertainty in the measured amount of decomposed antifoam following laboratory testing. In addition to analyzing reaction and decomposition products during melting, the resulting redox of the glasses formed after melting and cooling were measured (See Section 2.4).

The experimental parameters are summarized in Table 1 below. Six experiments were performed with SME product simulant processed using a typical formic/nitric flowsheet. Sludge batch (SB) 6 and SB8 sludge simulants were used for these experiments. The SB8 material was processed using formic/nitric additions and targeted $~ 500 \mathrm{mg}$ carbon (C) / kg melter feed slurry from the antifoam on an as-added basis. ${ }^{a}$ (As-added basis means the concentration of antifoam carbon assuming no decomposition.) This material was procured from excess stock previously prepared for other purposes and served as the baseline for SB8 feed. Three sub-samples from the SB8 baseline feed were taken and processed further prior to testing. To one sub-sample, raw antifoam was added to target $1600 \mathrm{mg} \mathrm{C} / \mathrm{kg}$ (as-added basis) and boiled for 6 hours to simulate a melter feed with decomposed antifoam. To a second sub-sample, a surrogate for decomposed antifoam was added to target $1400 \mathrm{mg} \mathrm{C} / \mathrm{kg}$ (as-added basis) to simulate a melter feed with decomposed antifoam. The surrogate was a commercially available PEG dimethyl ester (PEG-DE) (Sigma-Aldrich 445886: average molecular weight 500) representative of a likely antifoam decomposition product. ${ }^{\mathrm{b}}$

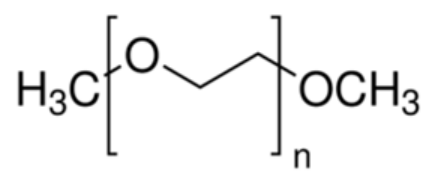

Figure 4. PEG-DE Structure, $\mathbf{n} \sim 11$.

PEG-DE has approximately 11 repeating $\mathrm{CH}_{2}-\mathrm{CH}_{2}-\mathrm{O}$ groups compared to the antifoam which has either 8 or 12 and should reasonably approximate the 'Remaining PEG Chain' as shown in Figure 4. To the third sub-sample, raw antifoam was added to target $1600 \mathrm{mg} \mathrm{C} \mathrm{/} \mathrm{kg}$ (as-added basis), but not boiled, to simulate a melter feed with a mixture of pristine and decomposed antifoam. All of the SB8 samples were heated in the furnace with an Ar purge.

Comparative experiments were performed with the SB6 material processed with formic/nitric additions. Two sub-samples were prepared from excess material sampled from the CEF phase I feed material.[3] That feed targeted $\sim 2200 \mathrm{mg} \mathrm{C} / \mathrm{kg}$ melter feed slurry from the antifoam. No additional processing was performed on either sub-sample. One sub-sample was heated with an Ar purge and the other sub-sample was heated with an Ar/air (targeting 1\% $\mathrm{O}_{2}$ ) purge mixture. Additional experiments were performed with SB6 material processed with glycolic/nitric additions. Two sub-samples were prepared from the CEF phase II feed material.[4] That feed targeted $\sim 2150 \mathrm{mg} \mathrm{C} / \mathrm{kg}$ melter feed slurry from the antifoam. To one sub-sample, additional raw antifoam to target a total of $\sim 3150 \mathrm{mg} \mathrm{C}$ / $\mathrm{kg}$ melter feed slurry from the antifoam was added. No additional processing was performed on either sample.

\footnotetext{
${ }^{a}$ In this report, antifoam concentrations are generally reported on a Carbon (C) basis because $\mathrm{C}$ is used to mass balance the acid and antifoam additions with the sludge

${ }^{\mathrm{b}}$ Once the TMS groups are cleaved off the antifoam molecule, the remaining PEG chain would be expected to be relatively inert and remain intact in the sludge during typical processing.
} 
Table 1. Experimental sample matrix for testing.

\begin{tabular}{|c|c|c|c|c|c|c|}
\hline $\begin{array}{l}\text { Flow } \\
\text { Sheet }\end{array}$ & Feed / Sample ID & Alternate ID & Purge & $\begin{array}{l}\text { Antifoam } \\
\text { Spike }\end{array}$ & $\begin{array}{c}\text { Antifoam C Conc. } \\
\text { (mg C / kg melter feed } \\
\text { slurry) }\end{array}$ & $\begin{array}{l}\text { Additional } \\
\text { Processing }\end{array}$ \\
\hline Formic & SB8-D3-No-Spike-(baseline) & SB8-Baseline & $\mathrm{Ar}$ & No & $513^{\mathrm{b}}$ & No \\
\hline Formic & SB8-D3_1000ppm-Antifoam-C-Spike-Boiled & SB8-AF-Boiled & $\mathrm{Ar}$ & Yes & $1646^{\mathrm{c}}$ & Boiled \\
\hline Formic & SB8-D3_1000ppm-Antifoam-C-Spike & SB8-AF & $\mathrm{Ar}$ & Yes & $1644^{\mathrm{c}}$ & No \\
\hline Formic & SB8-D3_1000ppm-PEG-C-Spike & SB8-PEG & $\operatorname{Ar}$ & Yes $/$ /PEG & $1371^{\mathrm{c}}$ & No \\
\hline Formic & CEF-P1-F-065-No-Spike-(baseline) & CEF1-Baseline & $\mathrm{Ar}$ & No & $2226^{\mathrm{e}}$ & No \\
\hline Formic & CEF-P1-F-065-No-Spike-(1\%O2) & CEF1- $1 \% \mathrm{O}_{2}$ & Ar/Air & No & $2226^{e}$ & No \\
\hline Glycolic & CEF-P2-100\%-S780-No-Spike (baseline) & CEF2-Baseline & $\mathrm{Ar}$ & No & $2147^{\mathrm{f}}$ & No \\
\hline Glycolic & CEF-P2-100\%-S780-1000ppmAntifoam-C-Spike & CEF2-AF & $\mathrm{Ar}$ & Yes & $3147^{\mathrm{g}}$ & No \\
\hline \multicolumn{7}{|c|}{$\begin{array}{ll}\text { a. } & \text { Antifoam C concentrations are target values (as-added basis) and do not account for any loss or assume any degradation. } \\
\text { b. } & \text { Antifoam concentration calculated for total antifoam additions based on SB8 SRAT/SME acid calculations. } \\
\text { c. } & \text { Antifoam concentration calculated for total antifoam additions based on SB8 SRAT/SME acid calculations and spike additions. } \\
\text { d. Spike was performed with equivalent amount of PEG (not antifoam 747), as described in the text. } \\
\text { e. Antifoam concentration calculated on total target antifoam additions from D. P. Lambert, "Batching Recipe: Nitric/Formic Acid Flowsheet Melter Feed," Internal Memorandum SRNL- } \\
\text { f. } \quad \text { A3100-2013-00021, Savannah River National Laboratory, Aiken, SC (2013). }\end{array}$} \\
\hline $\begin{array}{ll}\text { g. } & \text { Antifoa } \\
& 000008\end{array}$ & $\begin{array}{l}\text { a concentration calculated for total antifoam additions based or } \\
709 \text { and spike additions. }\end{array}$ & rell Quality Verificat & & ement & Feed," & \\
\hline
\end{tabular}


Formate, nitrate, glycolate, oxalate, and antifoam concentrations can be used to estimate the N, H, and C concentrations in each of the test feeds. The relative amounts of $\mathrm{N}, \mathrm{H}$, and $\mathrm{C}$ are used to estimate the flammability potential in the melter and the glass redox. In order to compare the test feeds $\mathrm{N}, \mathrm{H}$, and $\mathrm{C}$ concentrations were estimated from measured anion results (formate, nitrate, glycolate, and oxalate) and calculated antifoam additions. Because the relative antifoam concentration among samples was not expected to vary significantly (similar feeds and processing conditions) and reliable TOC measurements are not available, antifoam concentrations in feed samples were based on reported additions during feed preparations and do not account for any loss or assume any degradation during processing. The formate, nitrate, glycolate, oxalate and antifoam concentrations are summarized in Table 2. Figure 5 summarizes the molar quantities $\mathrm{N}, \mathrm{H}, \mathrm{C}$ and the molar ratios $\mathrm{N} / \mathrm{C}$ and $\mathrm{N} / \mathrm{H}$ in each test feed.

Table 2. Anion and antifoam concentrations in the testing feeds.

\begin{tabular}{|c|c|c|c|c|c|c|c|c|c|}
\hline & 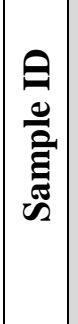 & 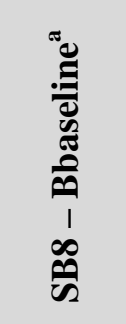 & 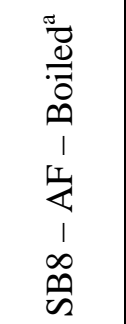 & $\begin{array}{l}\text { II } \\
\sum_{1} \\
1 \\
\infty \\
\infty \\
\omega\end{array}$ & $\begin{array}{l}0 \\
0 \\
11 \\
2 \\
1 \\
\infty \\
0 \\
\omega\end{array}$ & 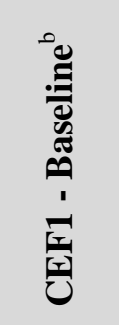 & 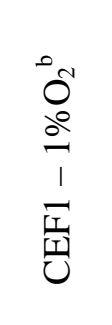 & 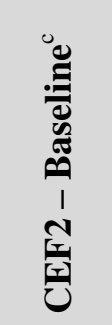 & 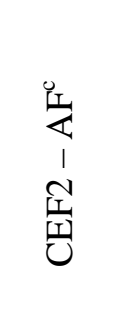 \\
\hline Analyte & & & & & & & & & \\
\hline Formate (mg/kg) & & 56500 & 56500 & 56500 & 56500 & 47200 & 47200 & 2345 & 2345 \\
\hline Nitrate (mg/kg) & & 30200 & 30200 & 30200 & 30200 & 17100 & 17100 & 62150 & 62150 \\
\hline Glycolate (mg/kg) & & - & - & - & - & - & - & 29450 & 29450 \\
\hline Oxalate (mg/kg) & & 475 & 475 & 475 & 475 & $<500$ & $<500$ & 978 & 978 \\
\hline Antifoam (mg C /kg) & & $513^{d}$ & $1646^{\mathrm{e}}$ & $1644^{\mathrm{e}}$ & $1371^{\mathrm{e}}$ & $2226^{\mathrm{f}}$ & $2226^{\mathrm{f}}$ & $2147^{\mathrm{g}}$ & $3147^{\mathrm{h}}$ \\
\hline
\end{tabular}

a. $\quad$ Measured anion values transcribed from D. C. Koopman and J. R. Zamecnik, "DWPF Simulant CPC Studies for SB8," US Department of Energy Report SRNL-STI-2013-00106, Savannah River National Laboratory, Aiken, SC (2013.

b. Measured anion values transcribed from M. E. Stone, "Acceptance of Harrell Batch 6B6i Formic Acid Flowsheet SRAT Product," Internal Memorandum SRNL-L3100-2013-00055, Savannah River National Laboratory, Aiken, SC (2013).

c. Measured anion values transcribed from D. P. Lambert, "Acceptance of Harrell Batch SB61 100\% Glycolic Nitric Acid Flowsheet SRAT Product," Internal Memorandum SRNL-L3100-2013-00118, Savannah River National Laboratory, Aiken, SC (2013).

d. Antifoam concentration based on SB8 SRAT/SME acid calculations.

e. Antifoam concentration based on SB8 SRAT/SME acid calculations and spike additions.

f. Antifoam concentration calculated on total target antifoam additions from D. P. Lambert, "Batching Recipe: Nitric/Formic Acid Flowsheet Melter Feed," Internal Memorandum SRNL-L3100-2013-00021, Savannah River National Laboratory, Aiken, SC (2013).

g. Antifoam concentration based on total antifoam additions from "Harrell Quality Verification Document Requirements for 100 percent GN Melter Feed,” document - SRNS PO-0000088709.

h. Antifoam concentration based on total antifoam additions from "Harrell Quality Verification Document Requirements for 100 percent GN Melter Feed"and spike additions. 


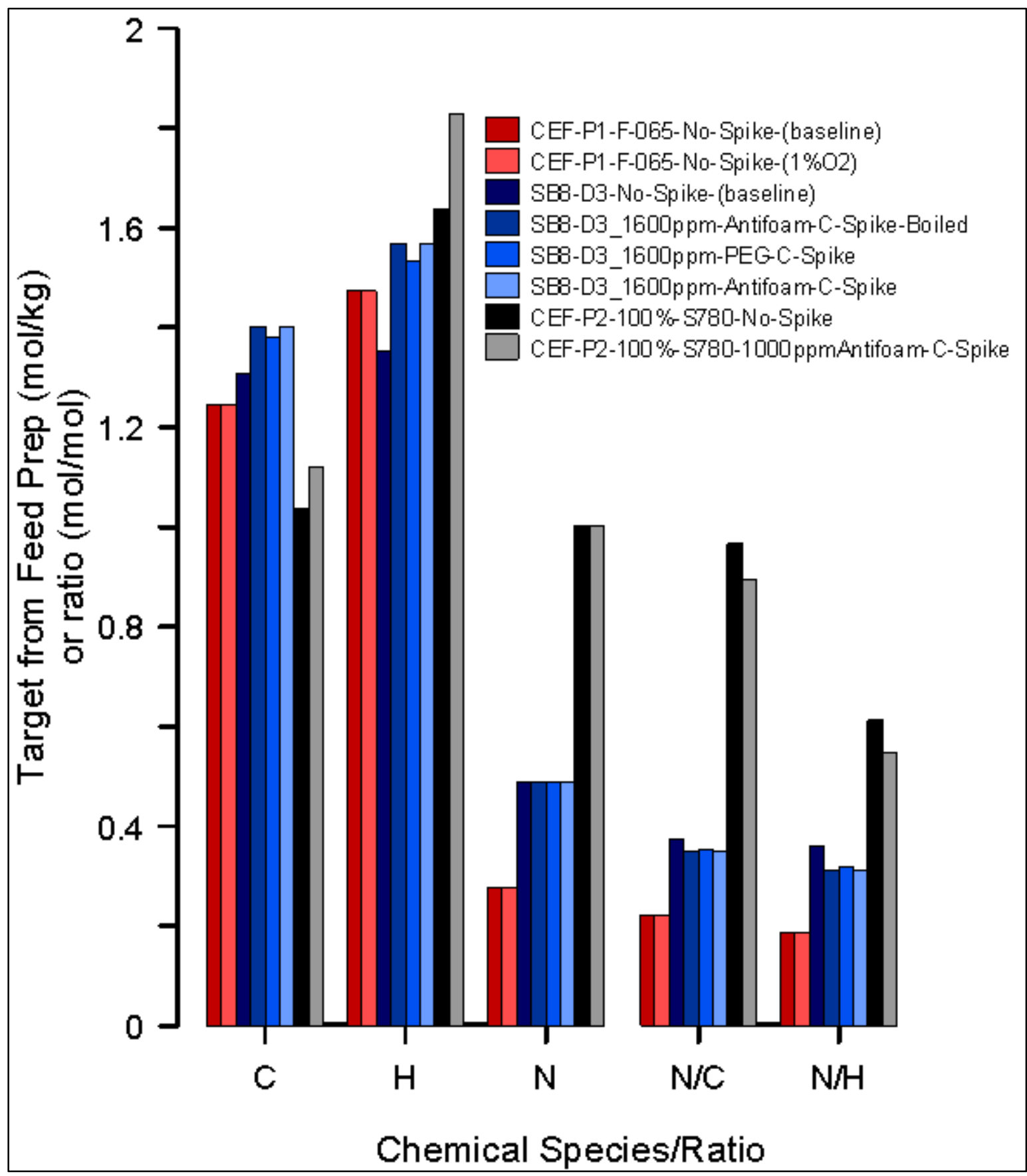

Figure 5. Calculated total molar concentration of $\mathrm{C}, \mathrm{N}$, and $\mathrm{H}$ and molar ratios of N/C and N/H for each feed.

\subsection{Procedure}

Approximately $10 \mathrm{~g}$ of prepared feed sample (slurry) was pipetted into a quartz vessel (through the outlet port) taking care to keep material off the vessel walls and ports. The vessel was then placed in a programmable furnace and the outlet and inlet ports were fitted and attached. A nominal $1.5 \mathrm{~L} / \mathrm{min} \mathrm{Ar}$ flow rate was established and each sample was heated using the furnace manual controls for approximately 1 hour to dry the slurry sample. The argon used was either from a liquid argon dewar or 
cylinder argon. Both sources were Air Liquide Alphagaz 1 purity with a minimum Ar concentration of 99.997\%, $5 \mathrm{ppm} \mathrm{O}_{2}$ maximum, and $20 \mathrm{ppm} \mathrm{N}_{2}$ maximum. Typical measured concentrations were 99.9995\% Ar, $<0.25 \mathrm{ppm} \mathrm{O}_{2}$, and $<5 \mathrm{ppm} \mathrm{N}_{2}$. During this period, the furnace set point was adjusted between approximately $70-140{ }^{\circ} \mathrm{C}$, but care was taken to ensure the sample temperature did not exceed $110^{\circ} \mathrm{C}$. Each sample drying was visually monitored and after drying was considered adequate, as evidenced by a 'desert pavement' appearance on the sample surface and an increase in the rate of temperature change in the sample, a pre-programmed furnace regimen was initiated and run for the duration of the test. The sample was heated at $10 \mathrm{~K} / \mathrm{min}$ to $550^{\circ} \mathrm{C}$ after which the reactions were mostly complete and the sample was heated at $15 \mathrm{~K} / \mathrm{min}$ to $1150^{\circ} \mathrm{C}$. The sample was held at $1150^{\circ} \mathrm{C}$ for 1 hour, and the furnace was shut off to allow the sample to cool in the furnace. The Argon purge was maintained until the sample temperature was below $200^{\circ} \mathrm{C}$. Afterwards, each vessel was broken open and an interior piece (not in contact with the quartz vessel) of the glassy product was removed and analyzed for redox.

\subsection{Redox Analysis}

The $\mathrm{Fe}^{2+} / \mathrm{Fe}^{3+}$ and $\mathrm{Fe}^{2+} / \mathrm{Fe}$ (total) ratios were determined from an absorption method using an ultraviolet visible spectrometer. Samples were dissolved in a sulfuric-hydrofluoric acid mixture, containing ammonium vanadate to preserve the $\mathrm{Fe}^{2+}$ content. Boric acid was added to destroy iron-fluoride complexes and ferrozine was added to form ferrous-ferrozine complexes for the determination of $\mathrm{Fe}^{2+}$ content. An additional measurement with ascorbic acid addition to reduce $\mathrm{Fe}^{3+}$ to $\mathrm{Fe}^{2+}$ with a second absorbance measurement was used to determine total Fe.[5]

\subsection{Gas Analysis}

The gas analysis system consisted of a sample pump, sample conditioner, a MKS MG2030 Fourier Transform Infrared (FTIR) spectrometer, and an Extrel CMS MAX300LG process mass spectrometer (MS). The sample conditioner removed water to a low humidity using a Nafion membrane dryer so that the sample to the analyzers would be dry; the dryer would also remove any $\mathrm{NH}_{3}$ if it were present. The gases analyzed and the methods used are shown in Table 3. Corrections for interferences were required for some of the MS measurements. For $\mathrm{N}_{2}$, the gases $\mathrm{CO}, \mathrm{N}_{2} \mathrm{O}$ and ethylene interfere with this measurement. The correction applied was to use the measured $\mathrm{CO}, \mathrm{N}_{2} \mathrm{O}$ and ethylene concentrations from the FTIR and MS sensitivity factors to subtract the effect of these gases on the $\mathrm{N}_{2}$ value as follows:

$$
\left[\mathrm{N}_{2}\right](\text { corrected })=\left[\mathrm{N}_{2}\right](\text { measured })-\mathrm{S}_{\mathrm{CO}}[\mathrm{CO}]-\mathrm{S}_{\mathrm{N}_{2} \mathrm{O}} \mathrm{F}_{\mathrm{N}_{2} \mathrm{O}}\left[\mathrm{N}_{2} \mathrm{O}\right]-\mathrm{S}_{\text {et }} \text { [ethylene }
$$

The ' $\mathrm{S}$ ' values are the sensitivity factors. The square brackets indicate concentrations. $\mathrm{S}_{\mathrm{N}_{2} \mathrm{O}} \mathrm{F}_{\mathrm{N}_{2} \mathrm{O}}$ is the sensitivity and fragmentation factor for the effect of $\mathrm{N}_{2} \mathrm{O}$ on the measurement of $\mathrm{N}_{2}$ at mass 28; this value was determined using a calibration gas. Sensitivity is approximately proportional to molecular weight and the sensitivity for $\mathrm{N}_{2}$ is defined to be 1.0, so the sensitivities for $\mathrm{CO}$ and ethylene were not measured and also set to 1.0. Similar corrections were done for the effects of $\mathrm{N}_{2} \mathrm{O}$ on $\mathrm{NO}$ and $\mathrm{CO}_{2}$. Because the MS data are normalized to $100 \%$, these corrections are not completely accurate as they do not account for the effect of changing the concentration of a measured species on the sum of all species. For all data points, the sum of all species present after corrections was 99.96 to $99.99 \%$. No corrections were required for the FTIR data. 
Table 3. Analyzers and Corrections Used for Each Species

\begin{tabular}{|c|c|l|}
\hline Gas & Method & Corrections \\
\hline $\mathrm{H}_{2}$ & MS & \multicolumn{2}{|c|}{ Zero background } \\
\hline $\mathrm{N}_{2}$ & MS & CO, $\mathrm{N}_{2} \mathrm{O}$, and ethylene \\
\hline $\mathrm{O}_{2}$ & MS & none \\
\hline $\mathrm{Ar}$ & MS & none \\
\hline \multirow{2}{*}{$\mathrm{NO}$} & MS & \multicolumn{2}{|c|}{$\mathrm{N}_{2} \mathrm{O}$} \\
\hline \multirow{2}{*}{$\mathrm{NO}_{2}$} & FTIR & none \\
\hline $\mathrm{CO}$ & MS & none \\
\hline \multirow{2}{*}{$\mathrm{CO}_{2}$} & FTIR & none \\
\hline $\mathrm{N}_{2} \mathrm{O}$ & FTIR & none \\
\hline $\mathrm{CH}_{4}$ (methane) & MS & \\
\hline $\mathrm{C}_{2} \mathrm{H}_{4}$ (ethylene) & FTIR & none \\
\hline $\mathrm{C}_{3} \mathrm{H}_{6}$ (propylene) & FTIR & none \\
\hline $\mathrm{C}_{2} \mathrm{H}_{2}$ (acetylene) & FTIR & none \\
\hline $\mathrm{H}_{2} \mathrm{O}$ (water) & FTIR & none \\
\hline & FTIR & none \\
\hline HMDSO (hexamethyldisiloxane) & FTIR & none \\
\hline & FTIR & none \\
\hline
\end{tabular}

\subsection{Results and Discussion}

\subsection{Heating Schedules}

In general, the heating schedule for each sample was consistent as evidenced by Figure 6, which depicts recorded thermocouple temperature as a function of time for each sample. Two samples exhibited significant deviations from the general trends. The CEF-P1-F-065-No-Spike-(baseline) plot (red) exhibited a discontinuity that was caused by an inadvertent loss of heating from the furnace when adjusting the ramp rate for the final heating stage and the thermocouple data for that sample was unreliable above $\sim 850^{\circ} \mathrm{C}$ due to a thermocouple malfunction identified (and corrected) after the run was completed. ${ }^{\text {a }}$ Additionally, the SB8-D3-No-Spike-(baseline) was held at higher temperatures for the initial 90 minutes of heating compared to the other samples. Regardless, the offgas data, presented subsequently indicates that the differences in heating rate appeared insignificant with regards to the species and quantities of offgas measured overall.

\footnotetext{
${ }^{\text {a }}$ Note temperature data above $\sim 850^{\circ} \mathrm{C}$ is not plotted for the CEF1-Baseline sample in subsequent plots due to the thermocouple malfunction during that run as the data above $\sim 850^{\circ} \mathrm{C}$ was not reliable.
} 


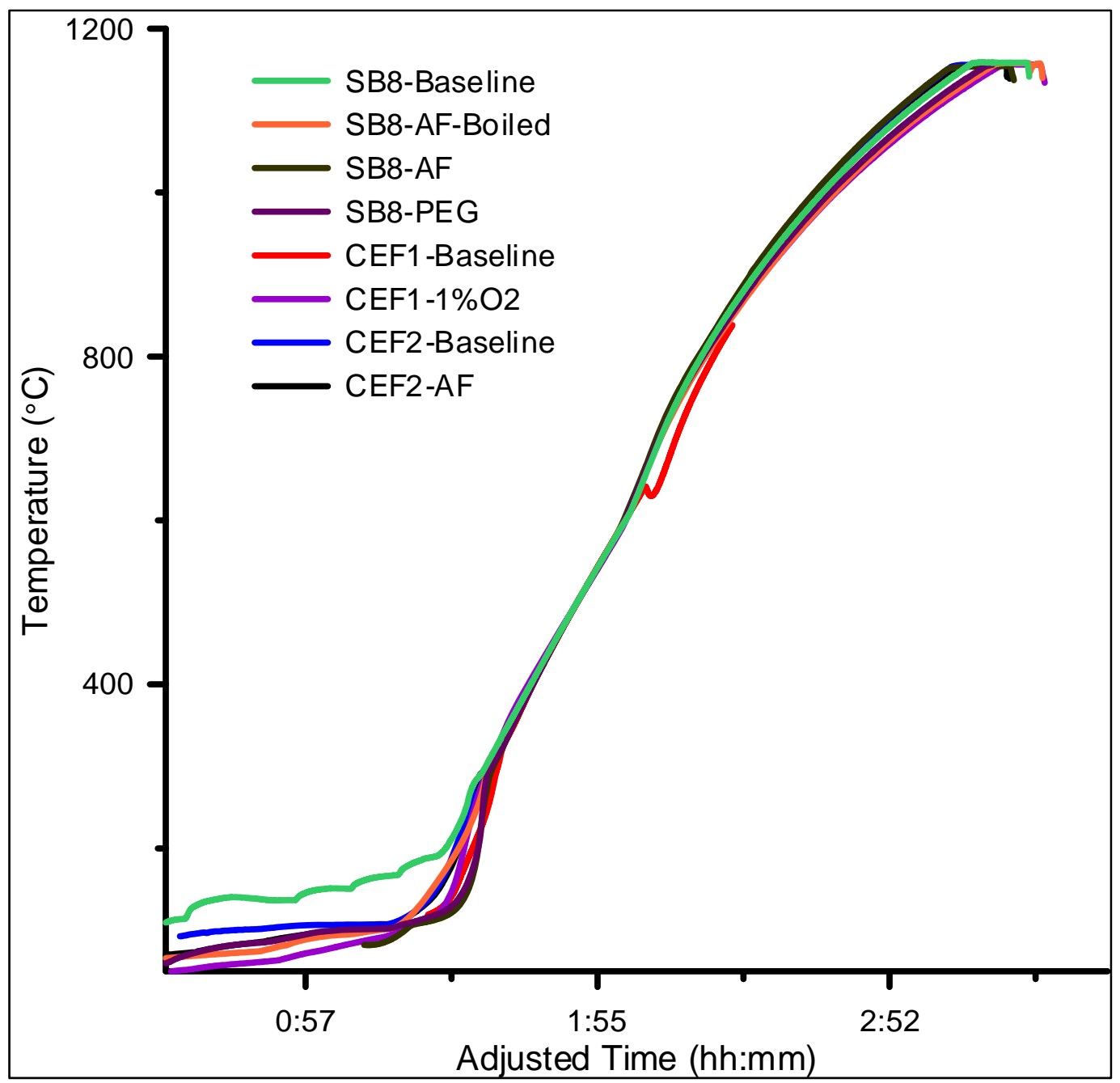

Figure 6. Thermocouple data demonstrating heating rate for each sample.

\subsection{Offgas Measurements}

The most prevalent species measured in the offgas were $\mathrm{H}_{2}, \mathrm{CO}, \mathrm{CO}_{2}, \mathrm{NO}, \mathrm{N}_{2} \mathrm{O}$, and $\mathrm{N}_{2}$. Also measured were small quantities $(<\sim 2 \mathrm{mmol})$ of $\mathrm{HMDSO}, \mathrm{NO}_{2}, \mathrm{CH}_{4}$, and $\mathrm{C}_{2} \mathrm{H}_{4}$ and very small quantities $(\sim 0.1$ mmol) of $\mathrm{C}_{3} \mathrm{H}_{6}$ and $\mathrm{C}_{2} \mathrm{H}_{2}$. $\mathrm{CO}_{2}$ and $\mathrm{NO}$ can be measured using either the FTIR or the MS instrument. The cumulative $\mathrm{CO}_{2}$ and NO offgas generation measured from each sample using FTIR and MS was compared to confirm the instruments were operating acceptably. Figure 7 summarizes the cumulative $\mathrm{CO}_{2}$ and NO offgas generation and confirms that the results were comparable for both instruments.

Offgas data was corrected for non-zero background prior to being used in calculations. In particular, residual air was observed at the start of some experiments as evidenced by non-zero $\mathrm{N}_{2}$ concentrations and air in-leakage was observed during some of the experiments as evidenced by gradual increases in $\mathrm{N}_{2}$ with time. In these cases, the $\mathrm{O}_{2}$ concentration was observed to trend similar to $\mathrm{N}_{2}$ indicating that the source was air and not offgas species. $\mathrm{N}_{2}$ production from CEF Phase 2 feed (with antifoam spike) and SB8-D3_1600ppm-Antifoam-C-Spike-Boiled feed was influenced by air in leakage detected heating at around 600C. In addition, the $\mathrm{N}_{2}$ production from the CEF Phase 1 feed $\left(1 \% \mathrm{O}_{2}\right)$ was indistinguishable from the $\mathrm{N}_{2}$ present in the air/Ar purge used for that experiment. The $\mathrm{N}_{2}$ offgas concentration was therefore not determined for that sample. 


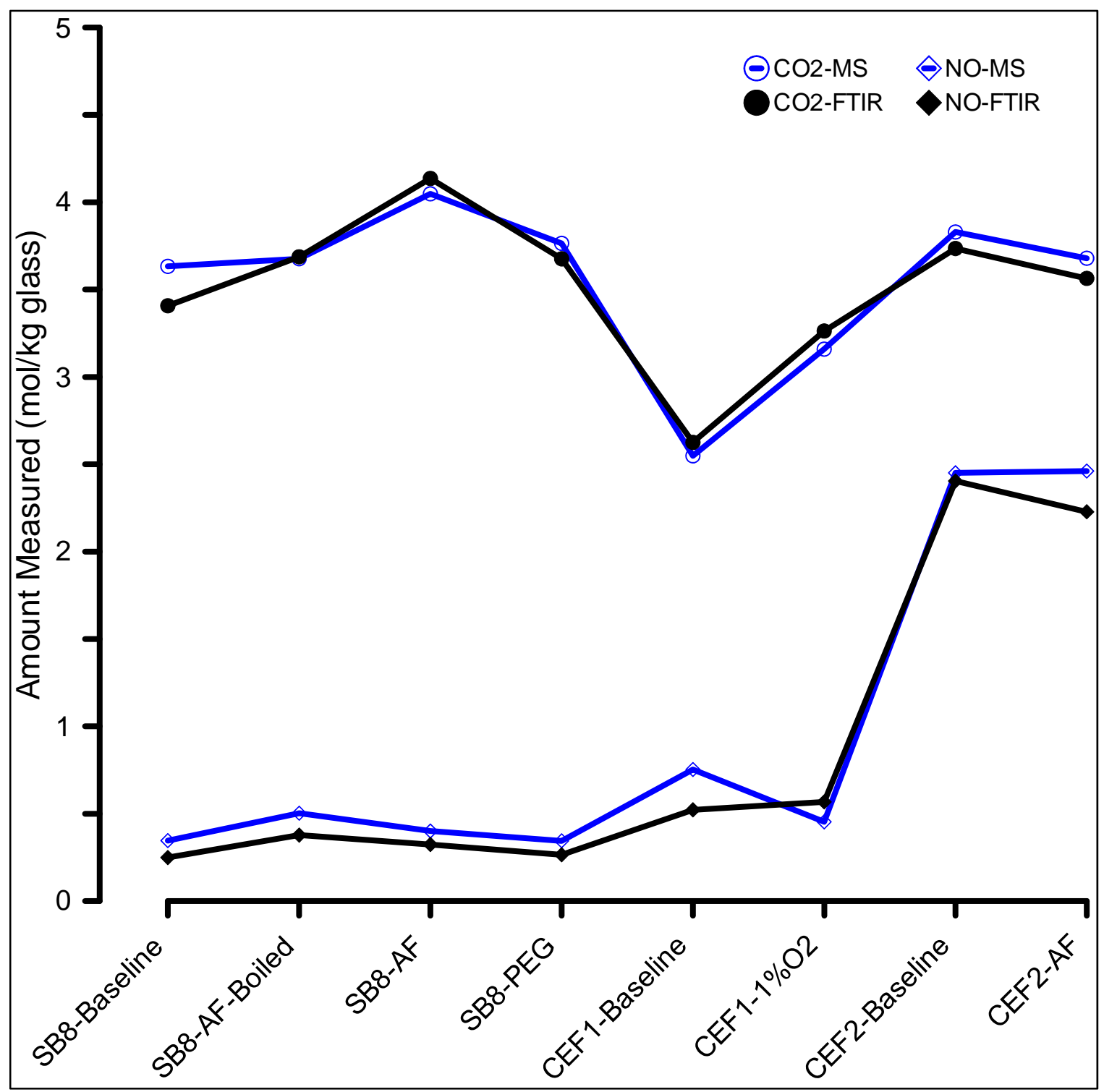

Figure 7. Total $\mathrm{CO}_{2}$ and NO offgas generation measured with FTIR and MS for each sample. (Lines are provided to aid the eye, they do not indicate trends among samples)

Figure 8 are plots of the $\mathrm{H}_{2}, \mathrm{CO}, \mathrm{CO}_{2}, \mathrm{NO}, \mathrm{N}_{2} \mathrm{O}, \mathrm{N}_{2}, \mathrm{NO}_{2}, \mathrm{CH}_{4}, \mathrm{C}_{2} \mathrm{H}_{4}, \mathrm{C}_{3} \mathrm{H}_{6}$, and $\mathrm{C}_{2} \mathrm{H}_{2}$ total generation measured in the offgas for each feed sample. The glycolic/nitric feed exhibited significantly lower $\mathrm{H}_{2}$ production accompanied by higher NO production compared to either formic/nitric feed. The overall offgas generation from the SB8 feeds was comparable. Differences in $\mathrm{H}_{2}$ production from the SB8 feeds appeared to be consistent with varying antifoam additions. The CO content from CEF Phase 1 feed (formic/nitric) was significantly higher ( 3x) than the other feeds independent of the test atmosphere ( $\mathrm{Ar}$ or Ar/air mixture). CEF Phase 1 feed also produced the most $\mathrm{H}_{2}$ accompanied by the least $\mathrm{CO}_{2}$. Evidently, the CEF Phase 1 feed produced an overall more reducing offgas compared to the other feeds. These results are supported by charge balance estimated from the $\mathrm{H}, \mathrm{C}, \mathrm{N}$, and $\mathrm{O}$ anions targeted in the feeds and listed in Table 2. The variations in the $\mathrm{NO}_{2}, \mathrm{CH}_{4}, \mathrm{C}_{2} \mathrm{H}_{4}, \mathrm{C}_{3} \mathrm{H}_{6}$, and $\mathrm{C}_{2} \mathrm{H}_{2}$ concentrations in the offgas were typical of observed instrumental variations. 


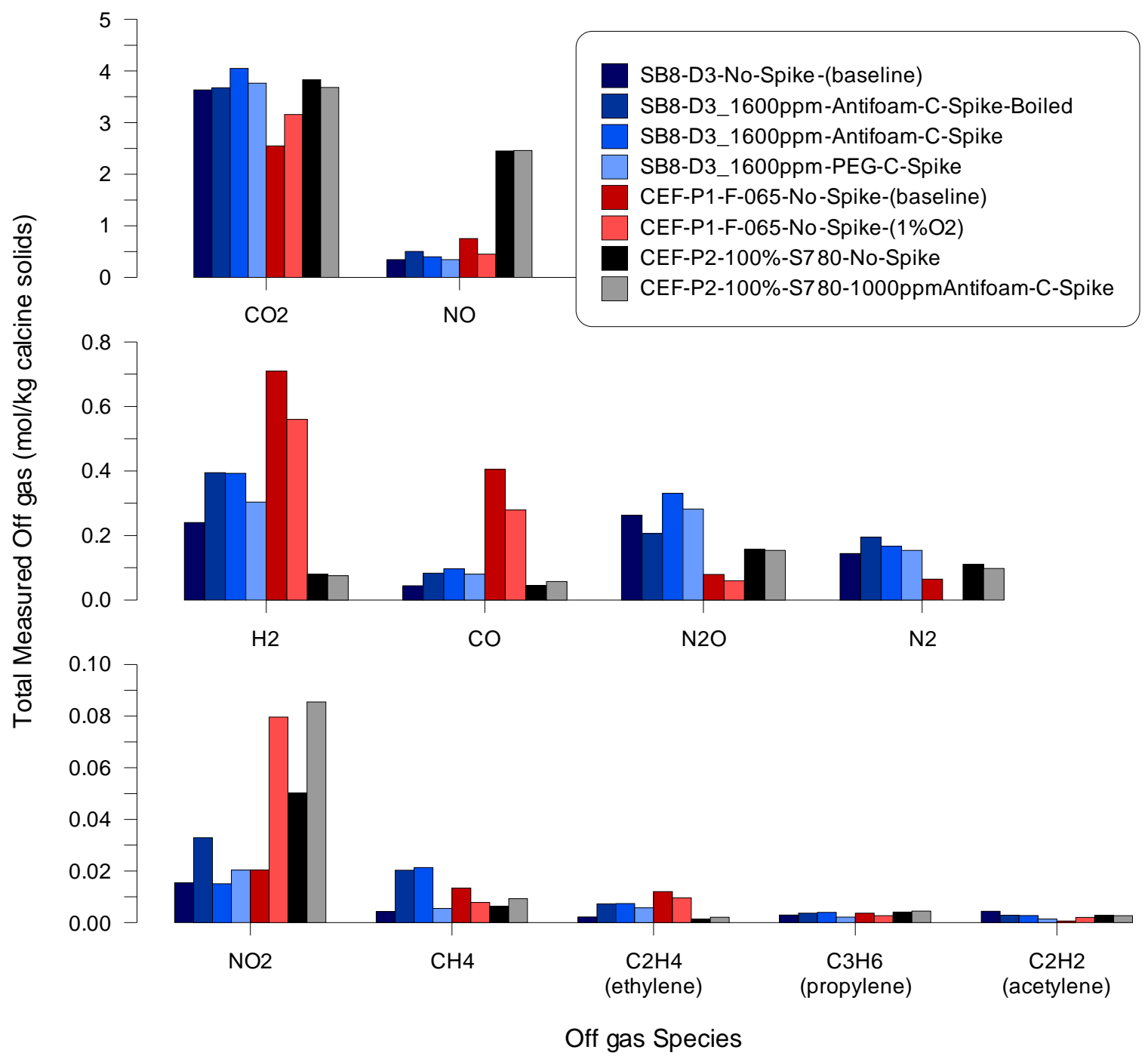

Figure 8. Total $\mathrm{H}_{2}, \mathrm{CO}, \mathrm{NO}_{2}, \mathrm{~N}_{2} \mathrm{O}, \mathrm{N}_{2}, \mathrm{CH}_{4}$, and $\mathrm{C}_{2} \mathrm{H}_{4}$ offgas generation for each sample.

Mole balances for $\mathrm{H}, \mathrm{C}, \mathrm{N}$, and $\mathrm{O}$ were performed using the calculated values listed in Table 2 and the measured offgas values. ${ }^{\text {a }}$ Figure 9 summarizes the calculated and total measured amounts of H, C, N, and O. Figure 10 is a plot of the difference between measured and calculated moles as a fraction of the measured value. In the line plot in Figure 10, positive values indicate the measured amount was greater than the calculated amount. The relative amounts of calculated and measured $\mathrm{C}, \mathrm{N}$, and $\mathrm{O}$ were generally within $20 \%$ of each other, indicating that the majority of $\mathrm{H}, \mathrm{C}, \mathrm{N}$, and $\mathrm{O}$ containing offgas species were measured. The measured $\mathrm{H}$ content was approximately $4 \mathrm{x}$ lower than calculated from the formic/nitric feeds and approximately 20x lower than calculated from the glycolic/nitric feeds. This result confirms that the majority of available $\mathrm{H}$ reacted to form water.

\footnotetext{
a The measured amount of $\mathrm{O}$ was calculated assuming that all $\mathrm{H}$ not measured reacted to form $\mathrm{H}_{2} \mathrm{O}$.
} 

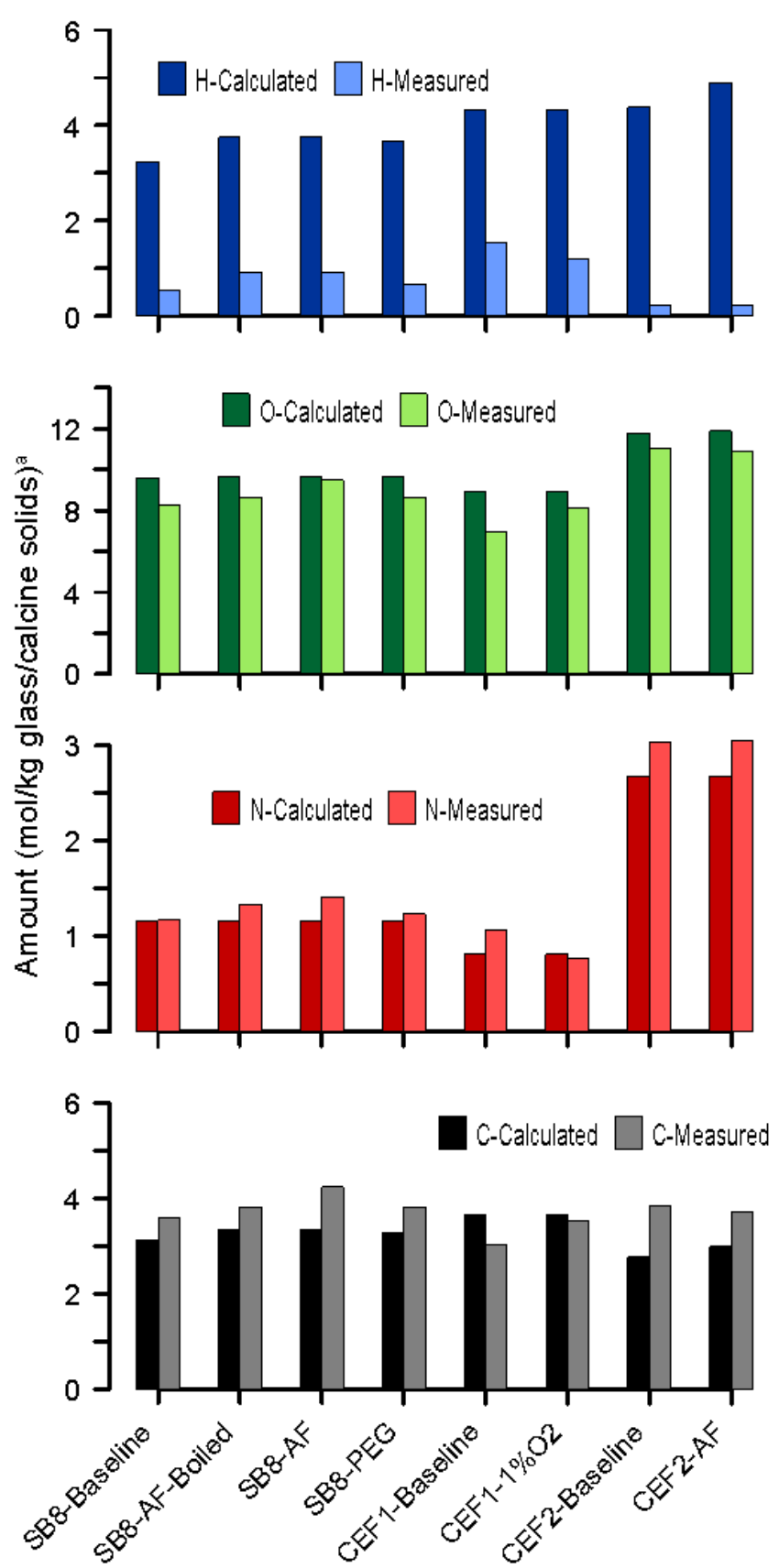

a. Calculated values are presented on calcine solids basis and measured values are presented on glass basis.

Figure 9. Total calculated and total measured (evolved) moles of $\mathrm{H}, \mathrm{N}, \mathrm{C}$, and $\mathrm{O}$ in each feed. 


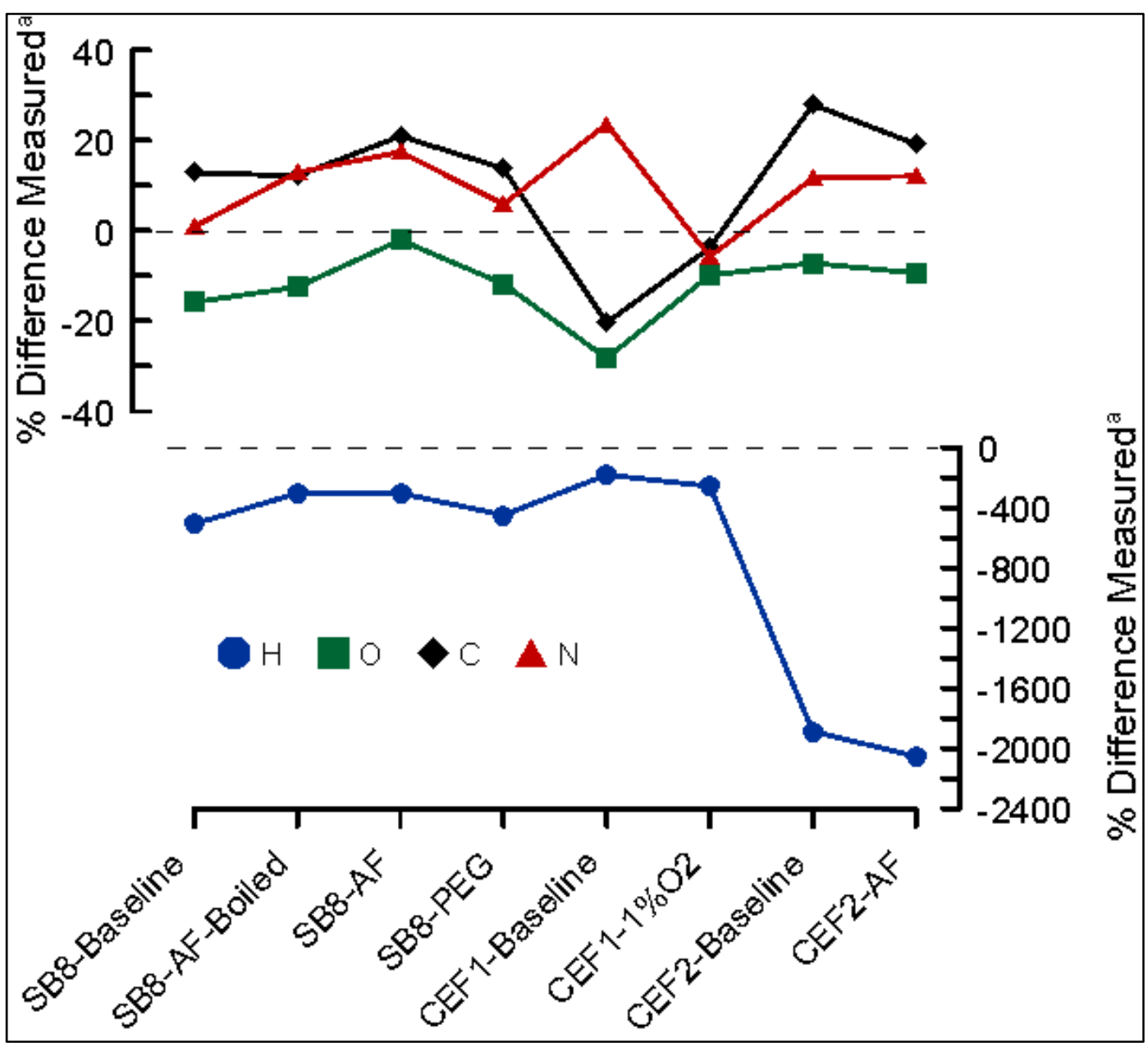

a. The \% difference is calculated from Figure 9 and is relative to the measured value. (i.e. a negative value indicates fewer moles were measured than calculated)

Figure 10. Differences (\%) between calculated and measured moles of $\mathrm{H}, \mathrm{O}, \mathrm{N}$, and $\mathrm{C}$ for each feed.

Figure 11, Figure 12, Figure 13 and Figure 14 are plots of the cumulative measured $\mathrm{H}_{2}, \mathrm{NO}, \mathrm{CO}_{2}$ and $\mathrm{CO}$, respectively, from each sample as a function of temperature. These plots provide insight into the reactions taking place during the experiments. These plots indicate that NO production was relatively rapid, occurring over a narrow temperature range, and nearly complete by approximately $300^{\circ} \mathrm{C}$. A significant fraction of the $\mathrm{H}_{2}$ production occurred simultaneously with the NO production but, $\mathrm{H}_{2}$ production did continue at a reduced rate until approximately $500^{\circ} \mathrm{C}$. Comparatively, approximately $1 / 3$ of the total $\mathrm{CO}_{2}$ and $\mathrm{CO}$ was produced simultaneously with $\mathrm{NO}$ and $\mathrm{H}_{2}$. After approximately $300^{\circ} \mathrm{C}$ the $\mathrm{CO}_{2}$ and $\mathrm{CO}$ production continued, at a reduced rate until approximately $800^{\circ} \mathrm{C}$, at which point no further reaction species were measured. The CEF-phase 1 feed results were an exception to these general trends. The CO production from the CEF-phase 1 feed exhibited similar behavior to the NO production.

These results indicate that nearly all the available $\mathrm{N}$ reacts and is evolved very rapidly at approximately $200-300^{\circ} \mathrm{C}$ accompanied by the release of approximately $1 / 3$ of the $\mathrm{C}$. The remaining $2 / 3 \mathrm{C}$ are slowly released fully oxidized as $\mathrm{CO}_{2}$. If $\mathrm{CO}_{2}$ was the only C-containing product the majority of the $\mathrm{CO}_{2}$ would have been expected to be released (measured) simultaneously with the liberated $\mathrm{N}$ compounds. 


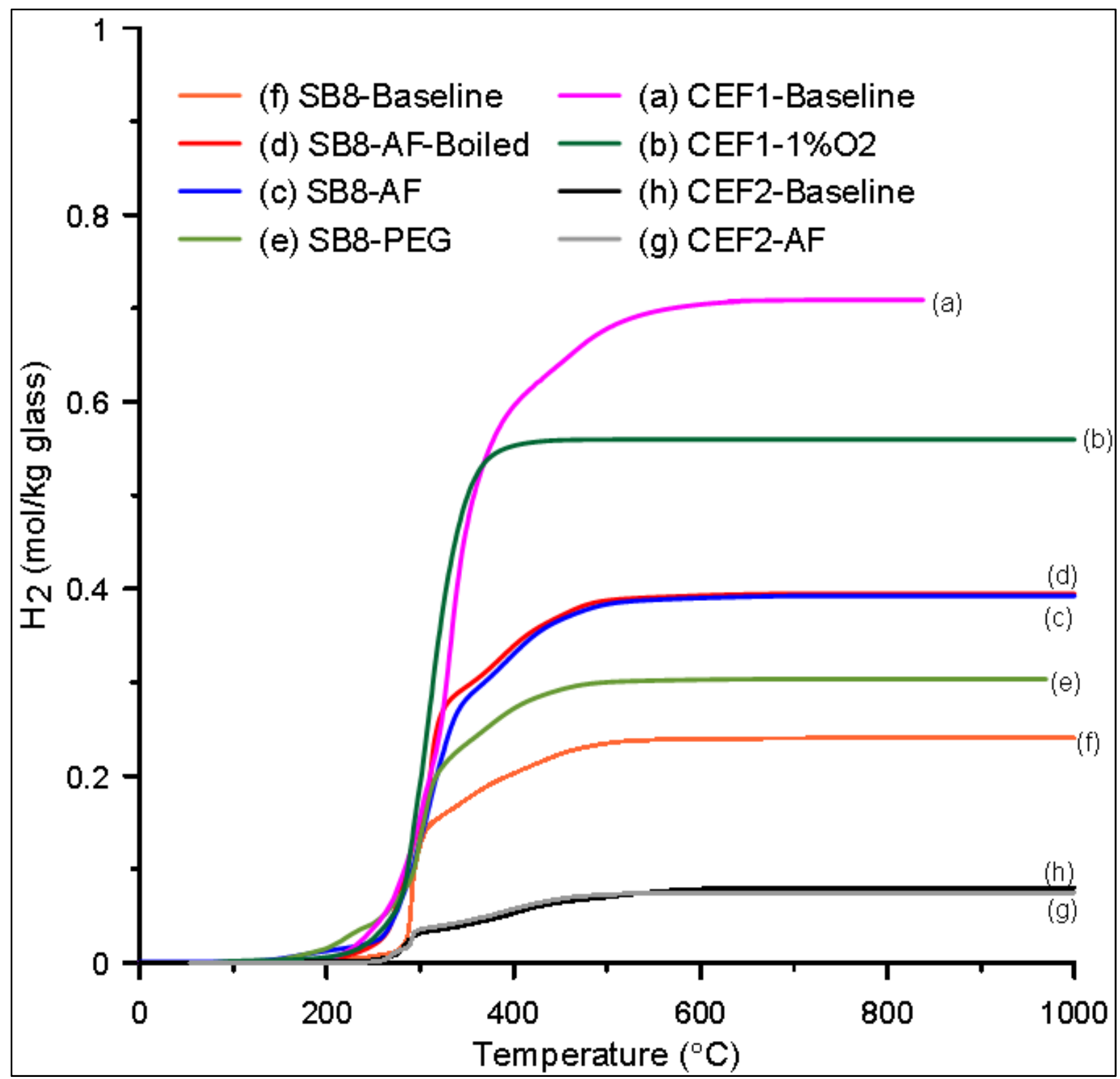

Figure 11. Cumulative $\mathrm{H}_{2}$ generation as a function of temperature from each sample. (Note temperature data above $\sim 850^{\circ} \mathrm{C}$ is not plotted for the $C E F 1$-Baseline sample due to a thermocouple malfunctioned during that run (Refer to Section 3.1). 


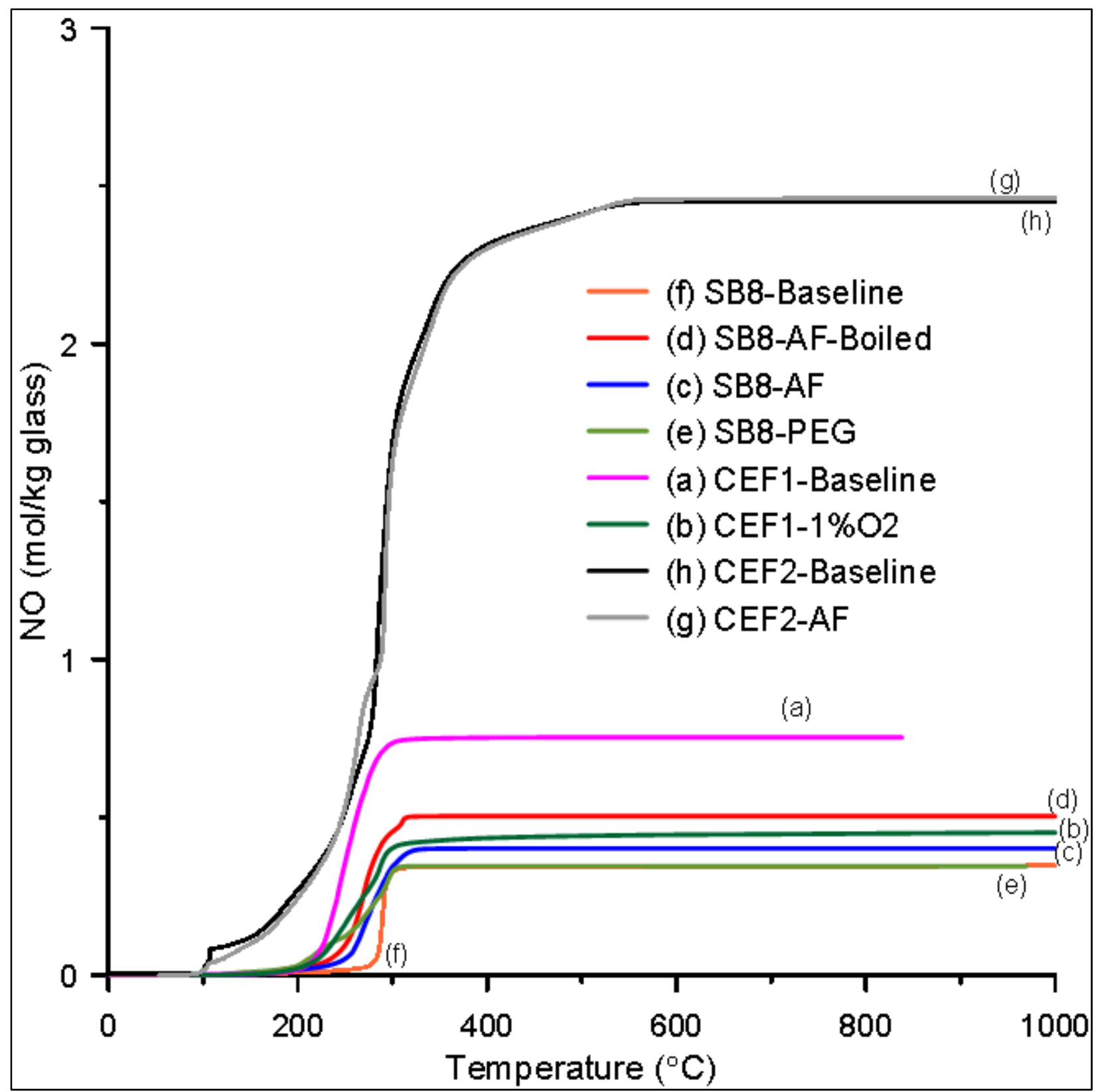

Figure 12. Cumulative NO generation as a function of temperature from each sample. (Note temperature data above $\sim 850^{\circ} \mathrm{C}$ is not plotted for the $C E F 1$-Baseline sample due to a thermocouple malfunctioned during that run (Refer to Section 3.1). 


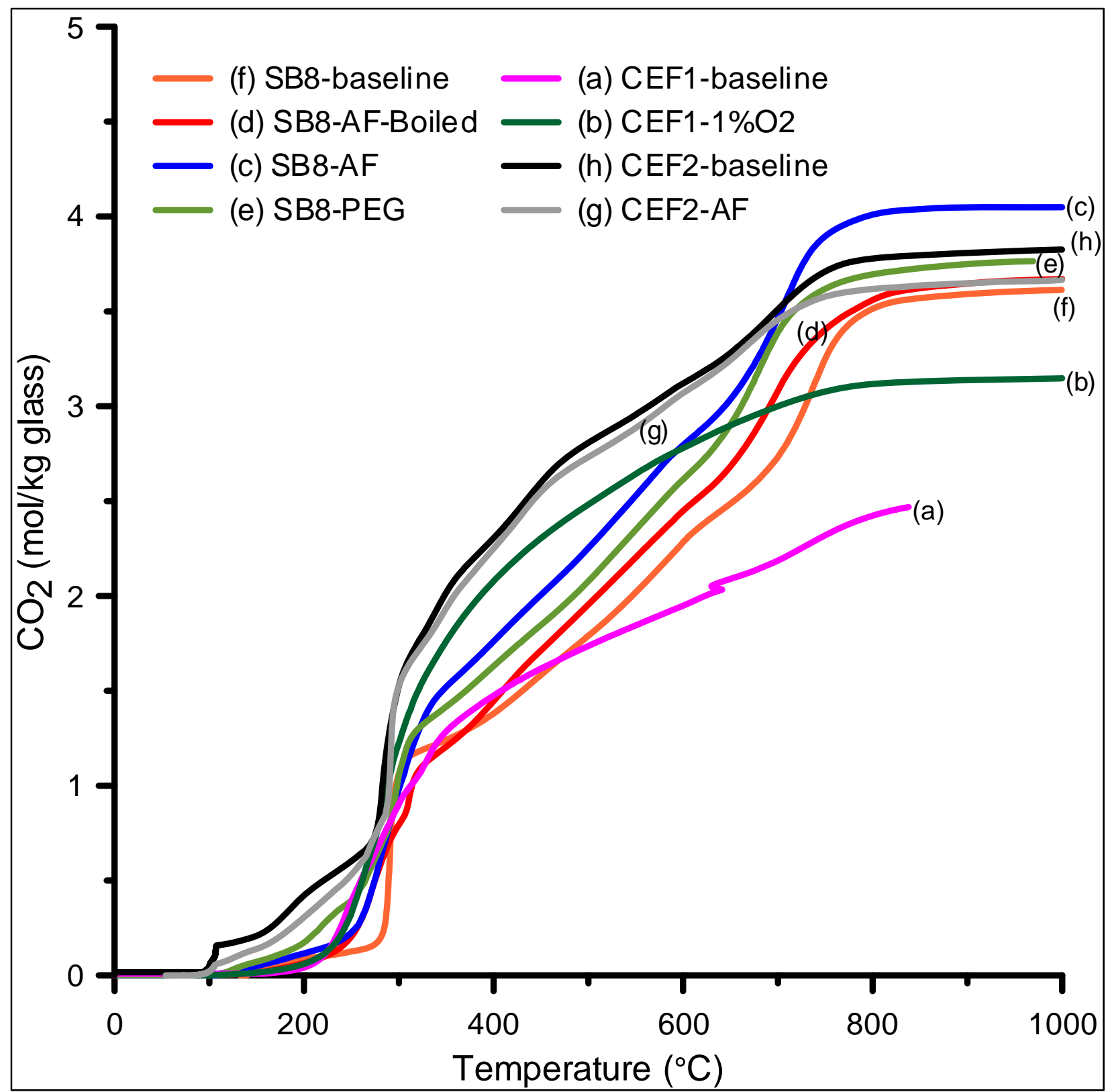

Figure 13. Cumulative $\mathrm{CO}_{2}$ generation as a function of temperature from each sample. (Note discontinuity and temperature data above $\sim 850^{\circ} \mathrm{C}$ is not plotted for the $\mathrm{CEF1-Baseline} \mathrm{sample} \mathrm{due}$ to a thermocouple malfunctioned during that run (Refer to Section 3.1). 


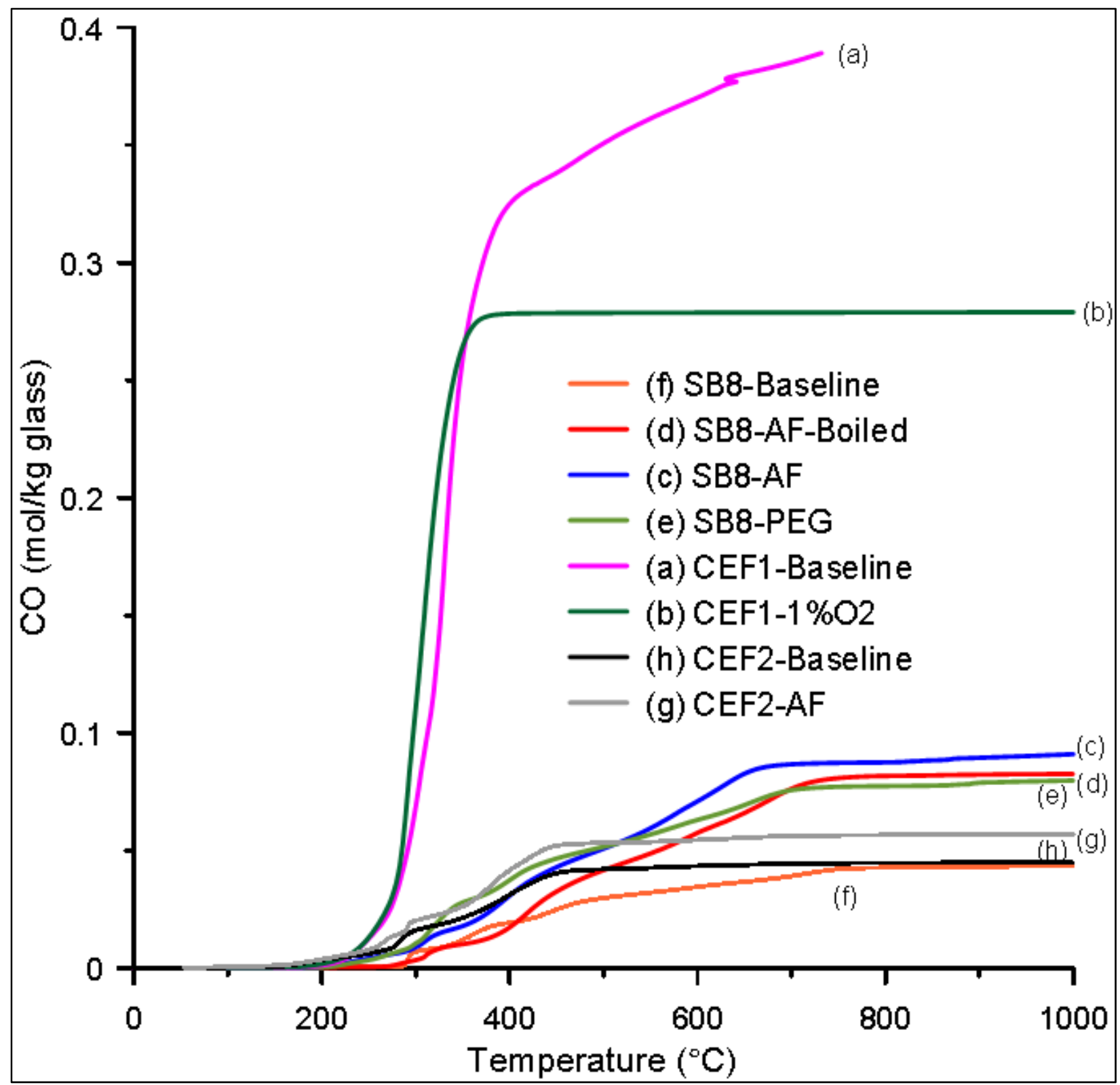

Figure 14. Cumulative $\mathrm{CO}$ generation as a function of temperature from each sample. (Note discontinuity and temperature data above $\sim 850^{\circ} \mathrm{C}$ is not plotted for the $\mathrm{CEF1-Baseline} \mathrm{sample} \mathrm{due}$ to a thermocouple malfunctioned during that run (Refer to Section 3.1). 
The data presented does not support the complete reaction of formate or glycolate with nitrate to form $\mathrm{N}_{2}$, $\mathrm{CO}_{2}$, and $\mathrm{H}_{2} \mathrm{O}$ as expressed below:

$$
\begin{aligned}
& \mathrm{Fe}_{2} \mathrm{O}_{3}+2 \mathrm{NaNO}_{3}+6 \mathrm{NaCO}_{2} \mathrm{H} \longrightarrow 2 \mathrm{FeO}+6 \mathrm{CO}_{2}+\mathrm{N}_{2}+3 \mathrm{H}_{2} \mathrm{O}+4 \mathrm{Na}_{2} \mathrm{O} \\
& \mathrm{Fe}_{2} \mathrm{O}_{3}+2 \mathrm{NaNO}_{3}+2 \mathrm{NaC}_{2} \mathrm{H}_{3} \mathrm{O}_{3} \longrightarrow 2 \mathrm{FeO}+4 \mathrm{CO}_{2}+\mathrm{N}_{2}+3 \mathrm{H}_{2} \mathrm{O}+2 \mathrm{Na}_{2} \mathrm{O}
\end{aligned}
$$

Multiple reactions with $\mathrm{NaCO}_{2} \mathrm{H}$ and $\mathrm{NaNO}_{3}$ are possible and it is speculated that an intermediate (sodium) carbonate species accompanied by oxidized $\mathrm{N}$ species is formed during the reaction such as the example reactions:

$$
\begin{aligned}
& 2 \mathrm{NaNO}_{3}+3 \mathrm{NaCO}_{2} \mathrm{H} \longrightarrow 2 \mathrm{NO}+\frac{5}{2} \mathrm{Na}_{2} \mathrm{CO}_{3}+\frac{3}{2} \mathrm{H}_{2} \mathrm{O}+\frac{1}{2} \mathrm{CO}_{2} \\
& 2 \mathrm{NaNO}_{3}+3 \mathrm{NaC}_{2} \mathrm{H}_{3} \mathrm{O}_{3} \longrightarrow 2 \mathrm{NO}+\frac{3}{2} \mathrm{Na}_{2} \mathrm{CO}_{3}+\frac{3}{2} \mathrm{H}_{2} \mathrm{O}+\frac{1}{2} \mathrm{CO}_{2}
\end{aligned}
$$

In both reaction scenarios, the $\mathrm{C}$ is still oxidized rapidly when the $\mathrm{N}$ is reduced. However, the (or a portion of the) $\mathrm{CO}_{2}$ formed during reaction produces $\mathrm{Na}_{2} \mathrm{CO}_{3}$ effectively trapping the $\mathrm{CO}_{2}$. The $\mathrm{CO}_{2}$ is then released over time as the $\mathrm{Na}_{2} \mathrm{CO}_{3}$ thermally decomposes and would explain the data in which the $\mathrm{CO}_{2}$ production continued with increasing temperature and was complete at approximately $800^{\circ} \mathrm{C}$, very near the decomposition temperature for $\mathrm{Na}_{2} \mathrm{CO}_{3}$ of $858^{\circ} \mathrm{C}$. This result is supported by previous research that has reported the complete reaction of $\mathrm{NaNO}_{3}\left(\right.$ or $\mathrm{NaNO}_{2}$ ) with $\mathrm{NaCO}_{2} \mathrm{H}$ is rapid, (less than 1 hour at $325^{\circ} \mathrm{C}$ ) and that $\mathrm{Na}_{2} \mathrm{CO}_{3}$ is anticipated when $\mathrm{NaNO}_{3}\left(\right.$ or $\mathrm{NaNO}_{2}$ ) are present with organics in nuclear waste feeds[6]. The implications of the reaction path(s) (in the feed) on the glass redox are discussed in the next section.

\subsection{Redox Measurements}

The equation used to predict redox has been modified several times during the operation of the DWPF Those modifications have consisted primarily of changes to the coefficients on terms in the equation and have been based feed compositions [7-9]. It follows that the predicted glass redox from the various feeds presented in this study demands different equations. Accordingly, glass redox predictions from feeds measured in this study were predicted using the following general equation:

$$
\frac{F e^{2+}}{\sum F e}=0.2358+0.1999 \bullet\left\{\left(2[\mathrm{~F}]+4[\mathrm{C}]+6[\mathrm{G}]+4\left[\mathrm{O}_{T}\right]+2.88\left[C_{A}\right]-\mathrm{X}[\mathrm{N}]-\mathrm{Y}[\mathrm{Mn}]\right) \bullet \frac{45}{T}\right\}+0.1[\mathrm{Ar}]
$$

where

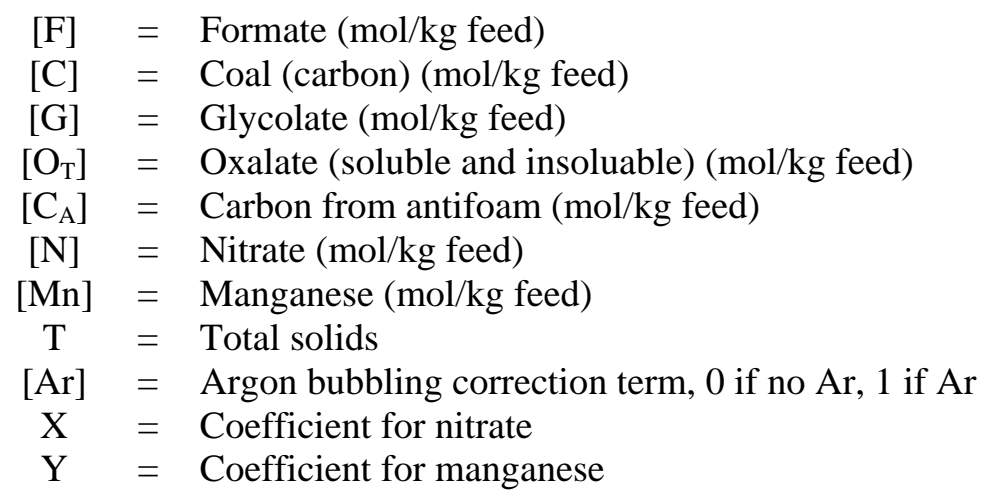


The measured redox of the glasses formed from each feed in this study along with predicted redox values based on the feed is listed in Table 4. The targeted redox and the measured redox using the closed crucible method for the three baseline feeds are also listed. In this study, the redox values measured for each SB8 feed with antifoam additions were comparable, suggesting that the state of the antifoam (pristine, degraded, or surrogate) did not significantly impact the glass redox.

The measured redox of all the glasses, excepting the $1 \% \mathrm{O}_{2}$ test, from the quartz crucible experiments exhibited greater redox values than calculated or measured using the closed crucible method. The measured redox using the quartz crucible was approximately $0.1-0.2\left(\mathrm{Fe}^{2+} / \mathrm{Fe}\right.$ total $)$ greater than the calculated redox and is in agreement with previous data that has indicated bubbling Ar will increase the predicted redox by approximately $0.1\left(\mathrm{Fe}^{2+} / \mathrm{Fe}\right.$ total).[7]

The presence of $\mathrm{O}_{2}$ had a definite impact on glass redox. The sample processed with $1 \% \mathrm{O}_{2}$ was fully oxidized although the offgas was similar to the same feed processed in Ar. There is little information available for glasses with redox values below $0.1\left(\mathrm{Fe}^{2+} / \mathrm{Fe}\right.$ total). Extrapolation of a linear fit to existing data would indicate $\mathrm{O}_{2}$ concentrations greater than approximately $10^{-2.6} \mathrm{~atm}(2500 \mathrm{ppm})$ will result in completely oxidized glass.[7] More recent fitting of that original data[10] has indicated that changes to the redox $\left(\mathrm{Fe}^{2+} / \mathrm{Fe}\right.$ total) are significantly diminished below a redox of $0.1\left(\mathrm{Fe}^{2+} / \mathrm{Fe}\right.$ total) regardless of $\mathrm{O}_{2}$ concentration suggesting that redox might be difficult to measure below $0.1\left(\mathrm{Fe}^{2+} / \mathrm{Fe}\right.$ total).

Table 4. Redox analysis results from resulting glass products.

\begin{tabular}{|l|c|c|c|c|c|}
\hline \multirow{2}{*}{ Sample } & \multicolumn{5}{c|}{ Fe $^{2+} /$ Fe Total $^{-}$} \\
\cline { 2 - 6 } & Target & Predicted & $\begin{array}{c}\text { Closed } \\
\text { Crucible }\end{array}$ & $\begin{array}{c}\text { CEF } \\
\text { Glass }\end{array}$ & $\begin{array}{c}\text { Quartz Vessel (this } \\
\text { study) }\end{array}$ \\
\hline SB8-Baseline & $0.10^{\mathrm{a}}$ & $0.21^{\mathrm{b}}$ & $0.19^{\mathrm{c}}$ & - & 0.30 \\
\hline SB8-AF-Boiled & - & $0.25^{\mathrm{b}}$ & - & - & 0.48 \\
\hline SB8-AF & - & $0.25^{\mathrm{b}}$ & - & - & 0.49 \\
\hline SB8-PEG & - & $0.24^{\mathrm{b}}$ & - & - & 0.46 \\
\hline CEF1-Baseline & $0.15-0.25^{\mathrm{d}}$ & $0.46^{\mathrm{e}}$ & $0.26^{\mathrm{d}}$ & $0.19^{\mathrm{f}}$ & 0.64 \\
\hline CEF1-1\%O & - & $0.46^{\mathrm{e}}$ & - & - & $\mathrm{all} \mathrm{Fe}^{3+}$ \\
\hline CEF2-Baseline & $0.25^{\mathrm{g}}$ & $0.02^{\mathrm{h}}$ & $0.25^{\mathrm{i}}$ & $\mathrm{all} \mathrm{Fe}^{3+\mathrm{i}}$ & 0.27 \\
\hline CEF2-AF & - & $0.06^{\mathrm{h}}$ & - & & 0.22 \\
\hline
\end{tabular}

a. $\quad$ D. C. Koopman and J. R. Zamecnik, “DWPF Simulant CPC Studies for SB8,” US Department of Energy Report SRNL-STI-201300106, Savannah River National Laboratory, Aiken, SC, (2013).

b. Calculated using equation (5) with $[\mathrm{N}]_{\text {coeff. }}=5,[\mathrm{Mn}]_{\text {coeff. }}=2,[\mathrm{G}]_{\text {coeff. }}=0$, and $[\mathrm{Ar}]_{\text {coeff. }}=0$.

c. $\quad$ F. C. Johnson and C. M. Jantzen, "Defense Waste Processing Facility Sludge Batch 8 Redox Evaluation," Internal Memorandum SRNL-L3100-2013-00001, Savannah River National Laboratory, Aiken, SC (2013).

d. M. E. Stone, "Acceptance of Harrell Batch 6B6i Formic Acid Flowsheet SRAT Product," Internal Memorandum SRNL-L3100-201300055, Savannah River National Laboratory, Aiken, SC (2013).

e. $\quad$ Calculated using equation (5) with $[\mathrm{N}]_{\text {coeff. }}=5,[\mathrm{Mn}]_{\text {coeff. }}=5,[\mathrm{G}]_{\text {coeff. }}=0$, and $[\mathrm{Ar}]_{\text {coeff. }}=0$.

f. $\quad$ F. C. Johnson, D. H. Miller, J. R. Zamecnik, and D. P. Lambert, "Alternate Reductant Cold Cap Evaluation Furnace Phase I Testing," US Department of Energy Report SRNL-STI-2014-00005, Savannah River National Laboratory, Aiken, SC (2014).

g. Personal Communication with D. P. Lambert and A. S. Choi (2014).

h. Calculated using equation (5) with $[\mathrm{N}]_{\text {coeff. }}=5,[\mathrm{Mn}]_{\text {coeff. }}=2,[\mathrm{G}]_{\text {coeff. }}=9$, and $[\mathrm{Ar}]_{\text {coeff. }}=0$.

i. $\quad$ Personal Communication with D. P. Lambert and F. C. Johnson (2014).

As was stated previously, the reaction of formate and glycolate with nitrate in which the available $\mathrm{N}$ reacts completely to $\mathrm{N}_{2}$ is not supported by the data presented. This is important because the coefficients in the glass redox equation are based on a particular set of reactions, namely that the available $\mathrm{N}$ reacts to form $\mathrm{N}_{2}$. The glass redox value from a feed that produced significant quantities of intermediate $\mathrm{NO}_{\mathrm{x}}$ species would be expected to be greater than predicted by equations (1) and (2) which, are based on the available $\mathrm{N}$ reacting to form only $\mathrm{N}_{2}$. To identify potential changes to the redox equation coefficients, reactions for the various nitrogen containing products from the formic/nitric flowsheet are as follows: 


\section{Formation of $\mathbf{N}_{2}$ :}

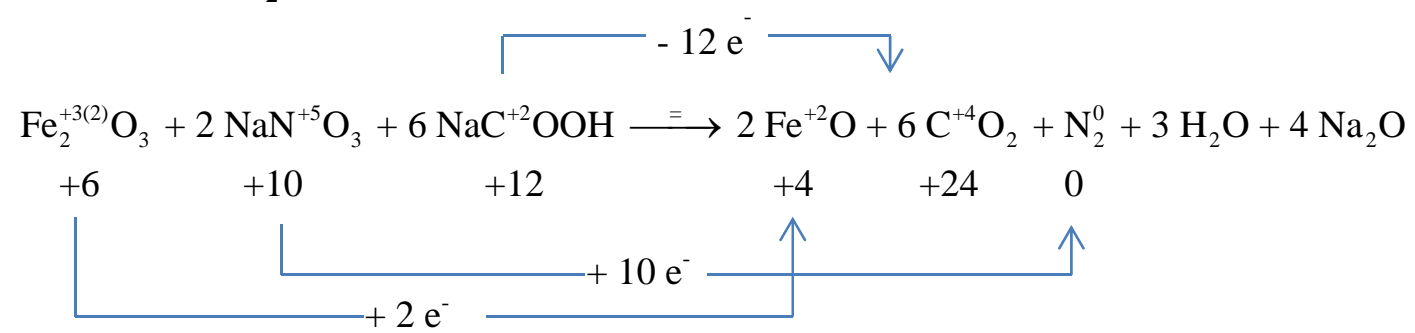

1 Fe reduced per 1 nitrate +3 formate. Coefficient on formate is 2 (12/6). Coefficient on nitrate is 5 $(10 / 2)$.

Formation of NO:

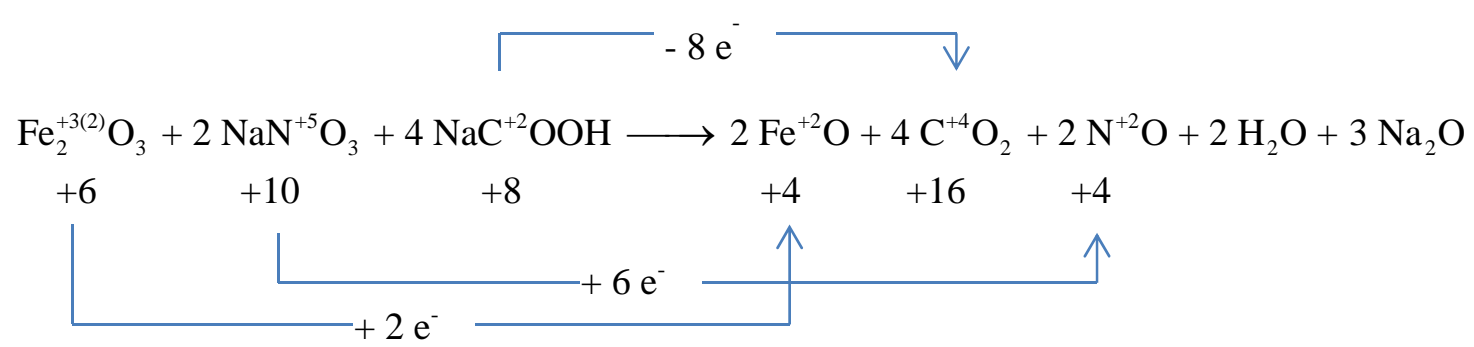

1 Fe reduced per 1 nitrate +2 formate. Coefficient on formate is $2(8 / 4)$. Coefficient on nitrate is $3(6 / 2)$.

Formation of $\mathrm{N}_{2} \mathrm{O}$ :

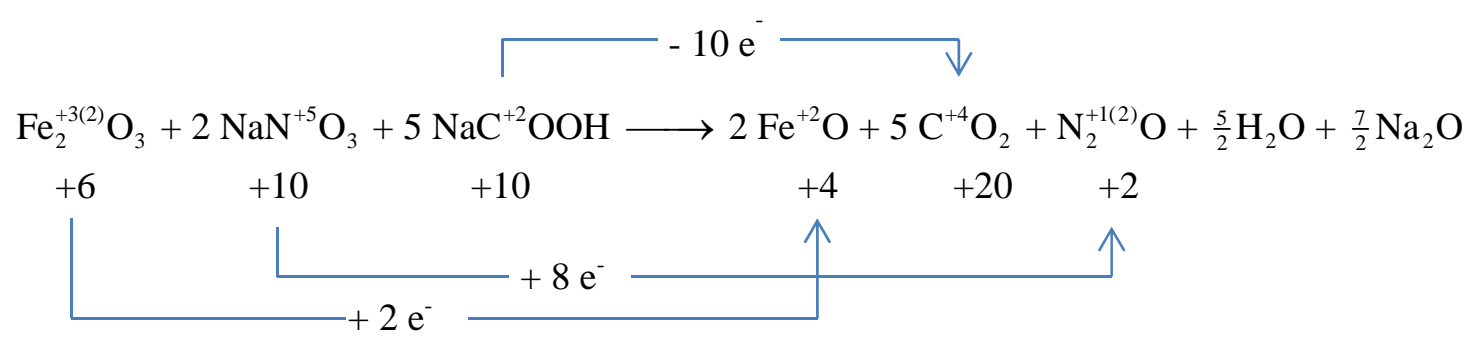

1 Fe reduced per 1 nitrate +2.5 formate. Coefficient on formate is $2(10 / 5)$. Coefficient on nitrate is 4 $(8 / 2)$.

Formation of $\mathrm{NO}_{2}$ :

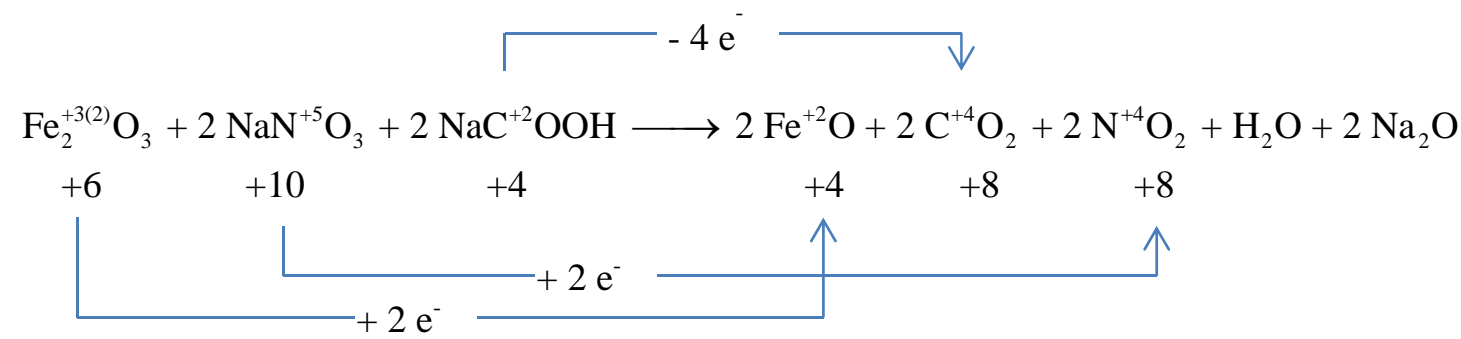

1 Fe reduced per 1 nitrate +1 formate. Coefficient on formate is $2(4 / 2)$. Coefficient on nitrate is $1(2 / 2)$. 
Similarly, reactions can be written for each glycolic/nitric flowsheet product as follows:

\section{Formation of $\mathrm{N}_{2}$ :}

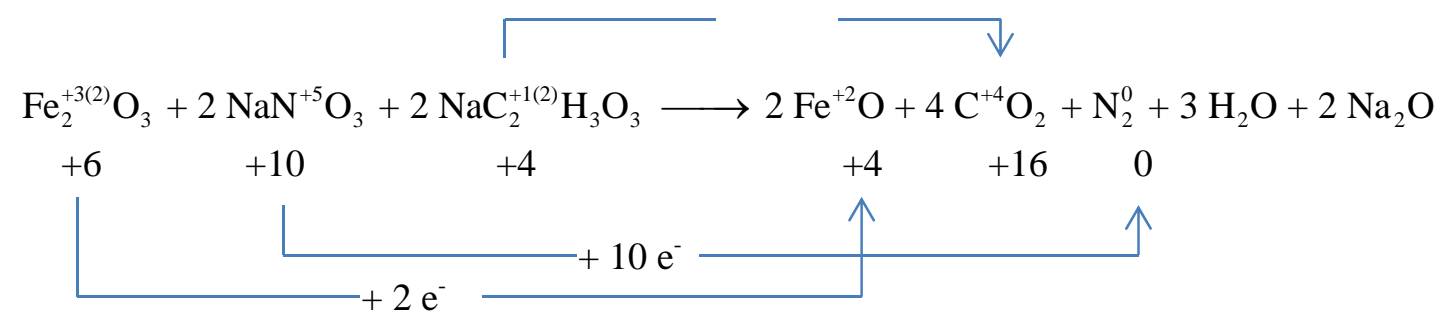

1 Fe reduced per 1 nitrate +1 glycolate. Coefficient on glycolate is $6(12 / 2)$. Coefficient on nitrate is 5 $(10 / 2)$.

Formation of NO:

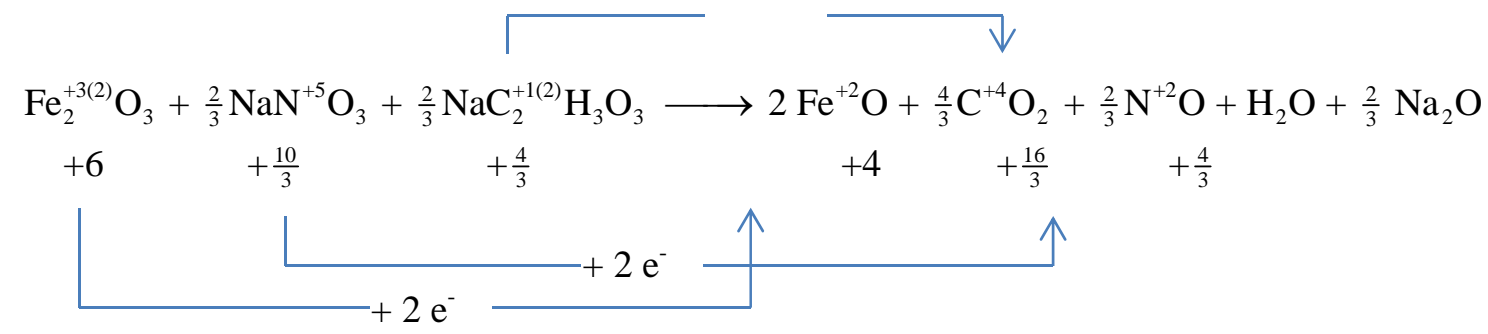

3 Fe reduced per 1 nitrate +1 glycolate. Coefficient on glycolate is 6 (4 / (2/3)). Coefficient on nitrate is 3 $(2 /(2 / 3))$.

Formation of $\mathrm{N}_{2} \mathrm{O}$ :

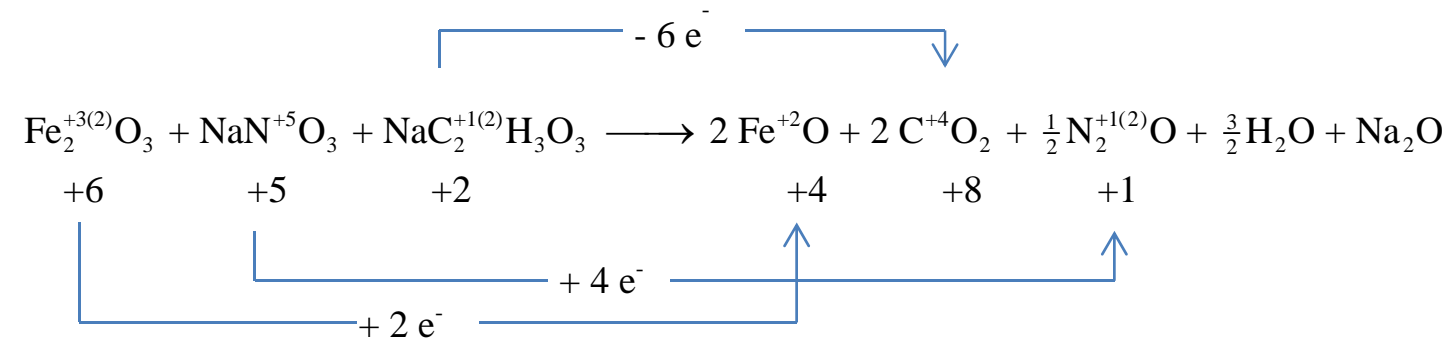

2 Fe reduced per 1 nitrate +1 glycolate. Coefficient on glycolate is 6 . Coefficient on nitrate is 4 .

\section{Formation of $\mathrm{NO}_{2}$ :}

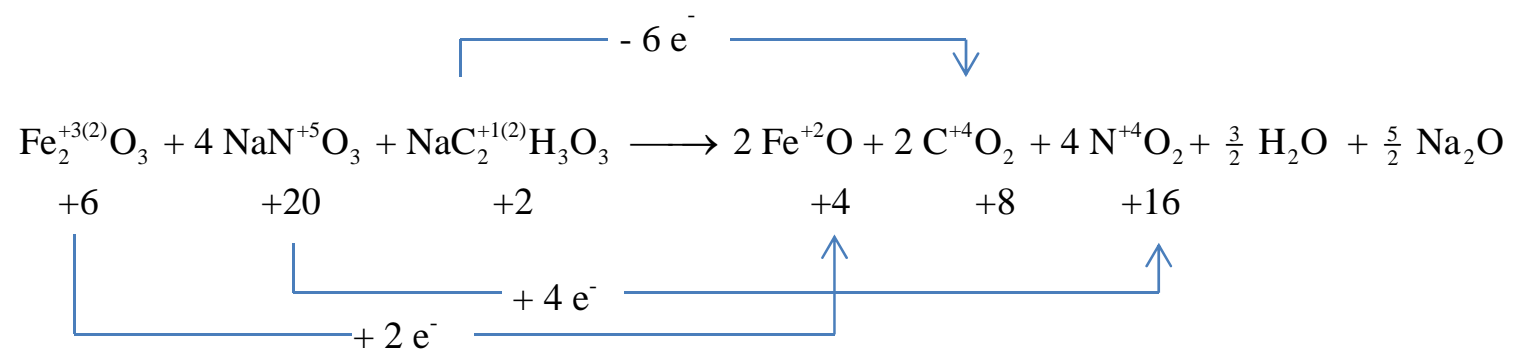

2 Fe reduced per 4 nitrate +1 glycolate. Coefficient on glycolate is $6(12 / 2)$. Coefficient on nitrate is 1 $(4 / 4)$. 
Table 5 summarizes the calculated coefficients for the nitric, formic, and glycolic terms based on the reactions described above. As can be seen, the glycolate and formate coefficients do not change, but the nitrate coefficient depends on the oxidation state of the $\mathrm{N}$ products. More specifically, the nitrate coefficient decreases as the $\mathrm{N}$ products become more oxidized. Table 6 lists the calculated nitrate coefficients from the measured offgas for each sample.

\section{Table 5. Calculated formate [F], glycolate [G], and nitrate [N] coefficients based on single} product reactions.

\begin{tabular}{|c|c|c|c|}
\hline \multirow{2}{*}{ Product(s) } & \multicolumn{3}{|c|}{ Reactant Coefficient } \\
\cline { 2 - 4 } & [F] & [G] & [N] \\
\hline $\mathrm{N}_{2}(100 \%)$ & 2 & 6 & 5 \\
\hline $\mathrm{N}_{2} \mathrm{O}(100 \%)$ & 2 & 6 & 4 \\
\hline $\mathrm{NO}(100 \%)$ & 2 & 6 & 3 \\
\hline $\mathrm{NO}_{2}(100 \%)$ & 2 & 6 & 1 \\
\hline
\end{tabular}

Table 6. Calculated nitrate coefficients [N] based on offgas measurements.

\begin{tabular}{|l|c|c|c|c|c|}
\hline \multirow{2}{*}{\multicolumn{1}{c|}{ Sample }} & \multicolumn{5}{|c|}{ Products (mol fraction) } \\
\cline { 2 - 6 } & $\mathbf{N}_{\mathbf{2}}$ & $\mathbf{N}_{\mathbf{2}} \mathbf{O}$ & \multicolumn{1}{c|}{$\mathbf{N O}$} & ${\mathbf{~} \mathbf{O}_{\mathbf{2}}}$ & {$[\mathbf{N}]_{\text {coeff. }}$} \\
\hline SB8-Baseline & 0.25 & 0.45 & 0.29 & 0.01 & 3.91 \\
\hline SB8-AF-Boiled & 0.29 & 0.31 & 0.38 & 0.02 & 3.84 \\
\hline SB8-AF & 0.24 & 0.47 & 0.28 & 0.01 & 3.92 \\
\hline SB8-PEG & 0.25 & 0.46 & 0.28 & 0.02 & 3.92 \\
\hline CEF1-Baseline & 0.12 & 0.15 & 0.71 & 0.02 & 3.36 \\
\hline CEF1-1\%O & 0.00 & 0.16 & 0.74 & 0.10 & 2.95 \\
\hline CEF2-Baseline & 0.07 & 0.1 & 0.81 & 0.02 & 3.22 \\
\hline CEF2-AF & 0.06 & 0.1 & 0.81 & 0.03 & 3.17 \\
\hline
\end{tabular}

The effect of the nitrate coefficient on the predicted glass redox for the samples measured in this study is demonstrated in Figure 15 and Figure 16. In those plots, the measured glass redox is plotted as a function of the predicted glass redox for varying nitrate coefficients using equation (5).

Considering the glass redox equation, the glass would be expected to become more reduced as oxygen is removed with the $\mathrm{N}$. Therefore, using the redox equation with the nitrate coefficient equal to 5 would be expected to predict a lower redox than measured based on the offgas results. Indeed, for all samples in this study, significant amounts of $\mathrm{NO}$ and $\mathrm{N}_{2} \mathrm{O}$ were observed in the offgas and the measured redox was greater than predicted using the redox equation with a nitric coefficient of 5 . For both glycolic and formic flowsheets, a nitrate coefficient between 3 and 4 would appear more appropriate based on these data. 


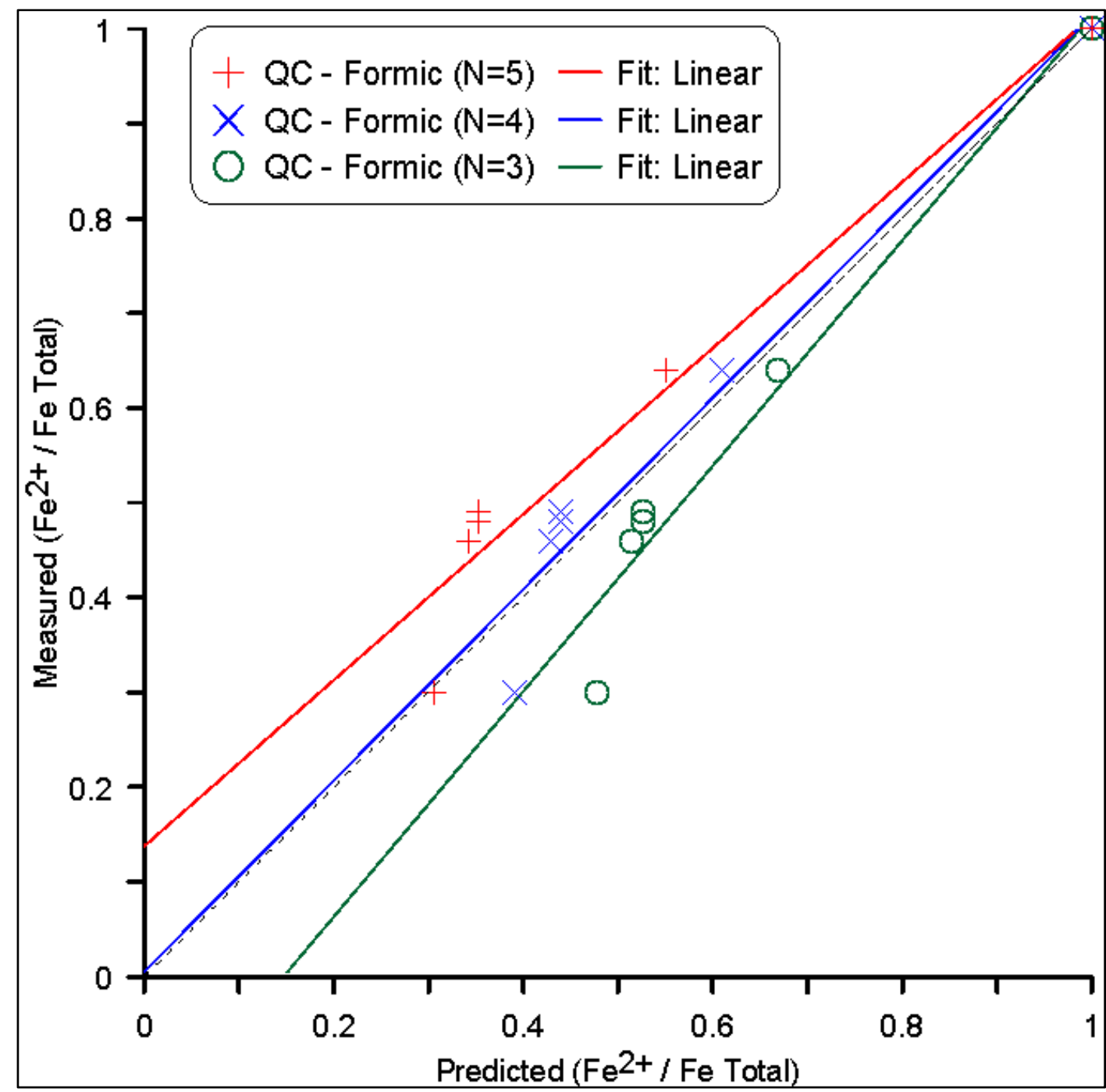

Figure 15. Measured vs. predicted $\mathrm{Fe}^{2+} / \mathrm{Fe}$ Total for formic/nitric flowsheet feed samples. 


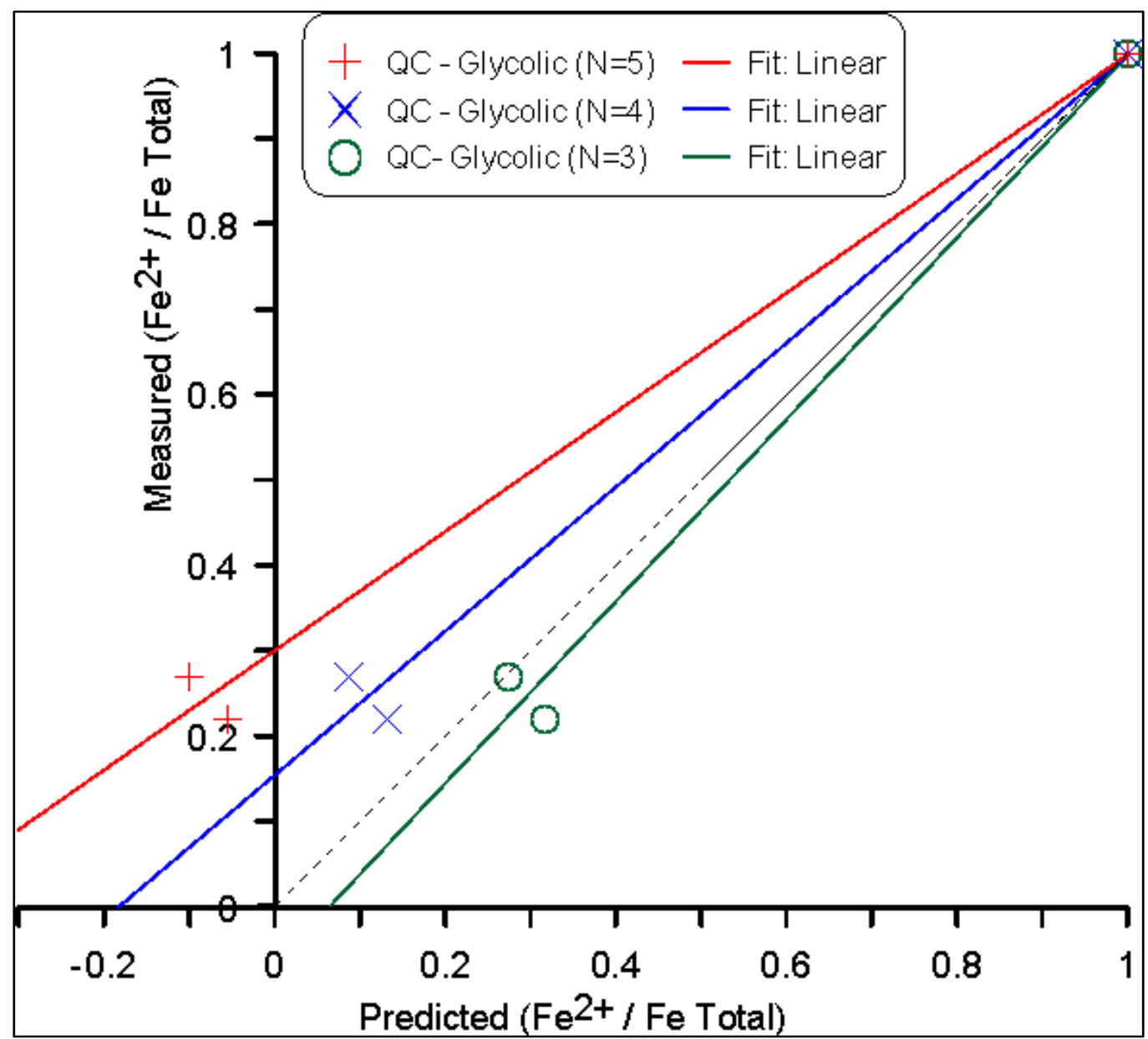

Figure 16. Measured vs. predicted $\mathrm{Fe}^{2+} / \mathrm{Fe}$ Total for glycolic/nitric flowsheet feed samples.

Substituting the calculated nitrogen coefficients from Table 6 and a non-zero [Ar] coefficient into the redox equation shown previously yields predicted redox values similar to those measured in this study and listed in Table 7.

Table 7. Measured and predicted redox values using the measured offgas results from this study.

\begin{tabular}{|l|r|c|c|}
\hline \multirow{2}{*}{\multicolumn{1}{c|}{ Sample }} & & \multicolumn{2}{c|}{ Fe $^{2+} /$ Fe Total } \\
\cline { 2 - 4 } & {$[\mathbf{N}]_{\text {coeff. }}$} & $\begin{array}{c}\text { Quartz Vessel } \\
\text { (this study) }\end{array}$ & Predicted $^{\mathbf{a}}$ \\
\hline SB8-Baseline & 3.91 & 0.30 & 0.40 \\
\hline SB8-AF-Boiled & 3.84 & 0.48 & 0.45 \\
\hline SB8-AF & 3.92 & 0.49 & 0.45 \\
\hline SB8-PEG & 3.92 & 0.46 & 0.44 \\
\hline CEF1-Baseline & 3.36 & 0.64 & 0.65 \\
\hline CEF1-1\%O 2 & 2.95 & all Fe $^{3+}$ & - \\
\hline CEF2-Baseline & 3.22 & 0.27 & 0.23 \\
\hline CEF2-AF & 3.17 & 0.22 & 0.29 \\
\hline
\end{tabular}

a. Calculated using equation (5) with [N] coefficients from Table 6 and non-zero $[\mathrm{Ar}]$ term. $\left([\mathrm{Mn}]_{\mathrm{coeff} .}=2\right.$, $[\mathrm{G}]_{\text {coeff. }}=6$, and $\left.[\mathrm{Ar}]_{\text {coeff. }}=1\right)$. 


\subsection{Conclusions}

A new method for quantitatively measuring the offgas species from simulated DWPF melter feed during heating was developed and used to measure the offgas as a function of temperature. This study compared offgas reactions from melting DWPF simulant slurry processed using formic/nitric and glycolic/nitric flowsheets containing various amounts of decomposed and pristine antifoam. As part of this study, a surrogate for decomposed antifoam was studied as a possible method for removing uncertainty in the measured amount of decomposed antifoam following laboratory testing. In addition to analyzing reaction and decomposition products during melting, the resulting redox of the glasses formed after melting and cooling were measured.

Results indicated that for the SB8 formic/nitric flowsheet, the concentration of antifoam did affect the offgas composition (including $\mathrm{H}_{2}$ generation) and glass redox but, the form of the antifoam (degraded, pristine, or surrogate) had a negligible effect. Antifoam concentration in the glycolic/nitric flowsheet feed had a negligible effect on the offgas composition (including $\mathrm{H}_{2}$ generation) and glass redox. The glycolic/nitric flowsheet feed had significantly less $(\sim 1 / 4)$ total $\mathrm{H}_{2}$ generation in the offgas during melting compared to the formic/nitric flowsheet feed and is thought to be related to different reaction paths among the flowsheets.

The overall composition of the offgas was composed primarily of $\mathrm{CO}_{2}, \mathrm{NO}, \mathrm{H}_{2}, \mathrm{CO}, \mathrm{N}_{2} \mathrm{O}, \mathrm{N}_{2}, \mathrm{NO}_{2}$, and $\mathrm{CH}_{4} . \mathrm{CO}_{2}$ and NO comprised $\sim 80 \%$ of the total emitted offgas from the formic/nitric flowsheet feeds and $\sim 90 \%$ of the total emitted offgas from the glycolic/nitric flowsheet feed.

The majority of nitrogen species (and most other gaseous species) were emitted over a relatively narrow temperature range from $200-400{ }^{\circ} \mathrm{C}$. A portion of the total $\mathrm{CO}_{2}$ was emitted simultaneously with the other gaseous species but, the majority was emitted more slowly until approximately $800^{\circ} \mathrm{C}$ at which point all significant offgas generation ceased. The data show that the $\mathrm{N}$-containing reactants were consumed well before the completion of $\mathrm{CO}_{2}$ evolution. The available $\mathrm{N}$ did not react to completion to form $\mathrm{N}_{2}$ (and $\mathrm{CO}_{2}$ ) but rather forms a significant amount of the intermediate products $\mathrm{NO}, \mathrm{NO}_{2}$, and $\mathrm{N}_{2} \mathrm{O}$ in addition to $\mathrm{N}_{2}$. This result is in contrast to the current understanding that the available $\mathrm{N}$ reacts to form $\mathrm{N}_{2}$. Instead, this work shows that the available $\mathrm{N}$ does not react to completion to form $\mathrm{N}_{2}$ but rather forms $\mathrm{NO}, \mathrm{NO}_{2}$, and $\mathrm{N}_{2} \mathrm{O}$ in addition to $\mathrm{N}_{2}$. Furthermore, the relative concentrations of $\mathrm{NO}, \mathrm{N}_{2} \mathrm{O}, \mathrm{N}_{2}$, and $\mathrm{NO}_{2}$ were different for each feed indicating that feed chemistry effects the reaction products.

Glass redox measurements from this study were consistent with predictions based on the measured offgas products (i.e. not all $\mathrm{N}$ reacting to form $\mathrm{N}_{2}$ ) and support the hypothesis that the chemical reaction path in the feed significantly affects the glass redox. The nitrogen coefficient ([N]) was found to be different for different sludge batches and it is possible that the nitrogen coefficient will change for each sludge batch. It follows that sludge batch dependent coefficients applied to the redox equation should be used to predict the redox for different sludge batches. 


\subsection{Recommendations for Future Work}

A limited number of feeds were examined in this study. Additional data is needed to substantiate the results from this study and to better understand feed chemistry and its effect on flammability and redox. Correlation of data from this method to existing experimental data including large-scale melter data should be performed to demonstrate the applicability of this method to measuring redox. With such correlations, this method would serve as a new robust tool to measure the reaction chemistry while simultaneously providing redox information for DWPF feeds.

The current methods would be improved with testing of well controlled feed compositions. Fluctuations in feed chemistry may result in unpredictable reaction products or glass redox. Different feed chemistries could be more or less susceptible to those same fluctuations which could lead to large changes in one feed but insignificant or non-measureable changes in another feed. Simpler test matrices, such as mixtures of only nitrate and glycolate should be considered for testing. Additional redox species such as $\mathrm{MnO} 2$ and Fe2O3 could then be added in a carefully planned series of experiments. Melter feed containing no oxalate and minimal antifoam should also be studied to minimize the effects of these species that are difficult to quantify. Feeds targeting different ratios of acid additions and molar ratios (i.e. N/C) should be tested to evaluate/develop redox equation coefficients. Additionally, the effects of the purge rate, time/temperature, trace O2, sample mass, vessel geometry, and other variables should be evaluated.

Further comparative testing should be performed to improve the understanding of the difference between the quartz vessel results the closed crucible results. Modification of the current experimental equipment to better mimic the closed crucible with and without an argon purge should be studied. The experiment should be modified so that there is no purge of the vessel, but still have the capability of measuring the composition of the offgas. Correlation of redox data from this method to the accepted closed crucible method and available large-scale melter data would demonstrate the applicability of this method to measuring redox.

Perhaps the most important task is to first better understand the implications of the underlying governing reactions and the effects of the experimental procedure on the glass redox and the offgas composition. This work has shown that the glass redox obtained correlates with the composition of the offgas products measured. However, it is known and has been indicated in the existing literature that the reduction efficiency of Fe3+ is dependent on the reductant and the efficiency can be influenced by the size, design, and any purge rate of the experiment.[6] In other words, the experimental setup can decouple the experimental results from the feed chemistry. For example, any purge in the system might force the glass to a thermodynamic equilibrium redox dictated by the partial pressure of oxygen. Therefore, it is specifically recommended that the experimental system described in this document be used to measure glass redox and offgas from feeds heated under varying partial pressures of oxygen (i.e. 10-6 - 10-2) and at different heating schedules to evaluate thermodynamic equilibrium relationships.

A better understanding of the redox reactions will facilitate a more specific and valuable approach to determine the requirements to consistently process a melter feed from the glycolic/nitric flowsheet or any future sludge batch. 


\subsection{References}

1. Personal Communication with D. P. Lambert, M. E. Stone and J. R. Zamecnik.

2. Personal Communication with A. S. Choi.

3. M. E. Stone, "Acceptance of Harrell Batch 6B6i Formic Acid Flowsheet SRAT Product," Internal Memorandum SRNL-L3100-2013-00055, Savannah River National Laboratory, Aiken, SC (2013).

4. D. P. Lambert, "Acceptance of Harrell Batch SB61 100\% Glycolic Nitric Acid Flowsheet SRAT Product," Internal Memorandum SRNL-L3100-2013-00118, Savannah River National Laboratory, Aiken, SC (2013).

5. E. W. Baumann, "Colorimetric Determination of Ferrous-Ferric Ratio in Glass," US Department of Energy Report DPST-87-304, Savannah River Laboratory, Aiken (1987).

6. J. L. Ryan, "Redox Reactions and Foaming in Nuclear Waste Glass Melting," US Department of Energy Report PNL-10510 (UC-940), Pacific Northwest Laboratory, Richland, WA (1995).

7. C. M. Jantzen and F. C. Johnson, "Impacts of Antifoam Additions and Argon Bubbling on Defense Waste Processign Facility (DWPF) REDuction/OXidation (REDOX)," US Department of Energy Report SRNL-STI-2011-00652, Savannah River National Laboratory, Aiken, SC (2012).

8. $\quad$ C. M. Jantzen and J. R. Zamecnik, "Preliminary Glycolate Term for the DWPF Redox Model," Internal Memorandum SRNL-L3100-2012-00149, Savannah River National Laboratory, Aiken, SC (2012).

9. Personal Communication with J. R. Zamecnik.

10. H. D. Schreiber and A. L. Hockman, "Redox Chemistry in Candidate Glasses for Nuclear Waste Immobilization," J. Amer. Ceram. Soc., 70 [8] pp. 591-94, (1987). 